\title{
Antioxidant Activity, Sugar Content and Phenolic Profiling of Blueberries Cultivars: A Comprehensive Comparison
}

\section{Onur Tolga OKAN ${ }^{1 *}$, Ilhan DENIZZ ${ }^{2}$, Nurettin YAYLI ${ }^{3}$, Ihsan Güngör ŞAT ${ }^{4}$, Mehmet ÖZ ${ }^{5}$, Gönül HATİPOĞLU SERDAR ${ }^{3}$}

\author{
${ }^{1}$ Karadeniz Technical University, Technology Transfer Office, 61080, Trabzon, Turkey; onurtolgaokan@ktu.edu.tr ( ${ }^{*}$ correspondingauthor) \\ ${ }^{2}$ Karadeniz Technical University, Faculty of Forestry, Department of Forest Industrial Engineering, 61080, Trabzon, \\ Turkey;ideniz@ktu.edu.tr \\ ${ }^{3}$ Karadeniz Technical University, Faculty of Pharmacy, Department of Pharmacognosis, 61080, Trabzon, \\ Turkey;yayli@ktu.edu.tr; gonulserdar@ktu.edu.tr \\ ${ }^{4}$ Ataturk University, Faculty of Agriculture, Department of Food Engineering, 25240, Erzurum, Turkey; igsat@atauni.edu.tr \\ ${ }^{5}$ Gümüshane University, Gümüşhane Vocational School, Department of Forestry, 29100, Gümüshane, Turkey; mehmetoz@gumushane.edu.tr
}

\begin{abstract}
Commercial blueberry production has been a viable industry throughout the world for 95 years; because of blueberry is a good source of antioxidant. Blueberries are especially rich in anthocyanin, a flavonoid with potent antioxidant capacity. The aim of this study was to compare the phenolic quantities, antioxidant activities, anthocyanin, sugar and phenolic compounds of blueberries produced in Turkey with those of similar blueberry varieties produced around the world. As a result of the conducted analysis, the total phenolic content (TPC) amount found in the berries was 77.26-215.12 mg GAE/100 g, the total flavonoid content (TFC) was 30.44-91.69 mg QE/100 $\mathrm{g}$ and the total anthocyanin content (TAC) was 43.03-295.06 mg c3GE/100 g. Examining the antioxidant activities of the berries, DPPH between 1.10-5.65 mg/ml, FRAP between 454.93$36832.96 \mu \mathrm{mol}$ troloks $/ 100 \mathrm{~g}, \beta$-Carotene between $40.66-86.48 \%$. It was determined that the natural berries contained much more phenolic compounds and higher antioxidant activity than that of the cultivars The result of HPLC analysis, chlorogenic acid is determined to be the dominant compound in all berries. Furthermore, fructose and glucose are found in all fruits in different quantities while sucrose is found in certain varieties of berries as well. At the end of the performed study the data indicate that wild and cultivars of blueberries are rich sources of antioxidants for local as well international industries importing this fruit for food processing and enormous products.
\end{abstract}

Keywords: antioxidant; blueberry; non-wood forest; phenolic content; sugar analysis

\section{Introduction}

Non-wood forest products (NWFPs, berries, wild herbs, mushroom) are bio products which are commonly consumed worldwide. NWFP are typically used in functional and premium class foodstuffs and nutraceuticals (Peltola, 2013). The recent global interest in the consumption of foods with high levels of functional properties and nutraceuticals compounds is gaining momentum (Zimmer et al., 2014). Among these types of foods, berries are one of the most important functional and nutraceutical foods in our diets (Kähkönen et al., 2001). Phenolic compounds are widely distributed in such plants where they act as attractants for certain insects, as free radical scavengers, and in defence against ultraviolet radiation, pathogens and predators (Zimmer et al., 2014; Solovchenko and Schmitz-Eiberger, 2003). In this context, blueberries (Vaccinium spp.) are known for being rich in bioactive compounds, including flavonoids, phenolic acids, tannins and anthocyanin's (Yang et al., 2014). The antioxidant capacity is always significantly correlated with the contents of these compounds (Kalt et al., 2000). The antioxidant activity of blueberries is relatively the most prominent amongst different bioactive properties (Häkkinen and Törrönen, 2000). Thus, blueberries are popular in grocery stores and are sold fresh as well as in processed forms such as in beverages, yogurt, jelly and jam (Seeram et al., 2006). 
640

Several studies were conducted to assess the antioxidant and phenolic capacity in wild and cultivar blueberries with the aim of obtaining comparative data and identifying the effect of regional variations (Taruscio et al., 2004; Brambilla et al., 2008; Yang et al., 2014). In this regard, the profile of flavonoid and phenolic compounds in nine Vaccinium species which included domestic blueberry cultivars were examined (Taruscio et al., 2004). It was found that there were inter and intra species differences between berry groups in total phenolics (TPH), anthocyanins (ACY) and antioxidant capacity. Catechin, epicatechin, myricetin and quercetin from flavan-3-ol and flavonol and caffeic, chlorogenic, $p$-coumaric, ferrulic and p-hydroxybenzoic from phenolic acid in $V$. corymbosum and $V$. angustifolium $\times V$. corymbosum cultivar species were also detected. $V$. corymbosum and $V$. angustifolium $\times V$. corymbosum cultivar contained a high amount of quercetin, exhibiting 86.4$102.5 \mu \mathrm{g} / \mathrm{g}$ and a high amount of chlorogenic acid, exhibiting 1261-1414 $\mu \mathrm{g} / \mathrm{g}$ (Taruscio et al., 2004). Another study (Yang et al., 2014) revealed the detection of gallic acid, caffeic acid, vanilic acid, syringic acid, $p$-coumaric acid and ferrulic acid in Vaccinium, while quercetin and kaempferol were not detected, however they found lower total phenolic content and a higher antioxidant capacity is shown by Vaccinium fruits. Another group studied (Brambilla et al., 2008) the phenolic profile and antioxidant capacity of juice made from a Vaccinium corymbosum cultivar. They reported that the main compound of juices from Vaccinium cultivars is chlorogenic acid. Also, the total content and relative distribution in anthocyanin's, chlorogenic acid, and quercetin of each juice was dependent upon the cultivar, and the total content was highly correlated to the antioxidant capacity. Climatic factors are effective on blueberry bioactive compounds. Annual and geographical factors appear to influence antioxidant value, although many years of study are needed to distinguish these effects from other biotic and abiotic factors that influence fruit phenolic content (Kalt et al., 2001).

Although blueberries are now grown commercially in the Southern Hemisphere in Australia, New Zealand and South American nations, until the 1930s (when introduced in Europe) blueberries were limitedly native to North America and commercially cultivated as highbush blueberries (Gao and Draper, 2010). Naturally acidic soils, which blueberries grow best (Ochmian et al., 2015), are found in the Black Sea region of Turkey. This region is also where the native blueberry (low bush) species have grown for hundreds of years. However, in the year 2000, the highbush blueberry cultivation started in Turkey were introduced from some western countries those originally gotten from USA. Apart from Turkey, wherever high bush blueberry cultivation is done, the grown plants have been studied for their bio significance and chemical composition (Celik, 2009).

Interestingly so far, no studies have been conducted on the blueberry cultivar samples in Turkey which are currently consumed not only by the Turkish population but are also exported to other countries as fresh berries and in different forms of processed foods (Ercisli and Celik, 2009).

In light of this, the purpose of our comprehensive study was to examine the phenolic composition, total anthocyanin, total phenols, and antioxidant activity of wild and cultivated blueberries grown in Turkey. It is important to understand the relationship between phenolic and agronomical parameters or future selection of blueberry genotypes having improved nutritional quality when consumed as fresh or as processed blueberry products.

\section{Materials and Methods}

Chemicals

Folin-Ciocalteu's phenol reagent, 2,4,6-Tripyridyl-striazine (TPTZ), 2,2-diphenyl-1-picrylhydrazyl (DPPH), Trolox (6-hydroxy-2,5,7,8-tetramethylchroman-2-carboxylic acid) were purchased from Sigma Chemical Co. (St Louis, MO, USA). Standard phenolic compounds were obtained from Sigma-Aldrich (Steinheim, Germany). The rest of the reagents used in the study were obtained from Merck, Darmstadt, Germany through its local authorized distributors.

\section{Plant material}

A total of 28 samples of blueberries were obtained from the Black Sea region situated in north eastern Turkey, during the peak growing season in 2012, 2013 and 2014. Berries were harvested from Giresun (Bulancak), Trabzon (Hayrat and Kaşüstü) and Rize provinces. The samples were immediately frozen and stored at $-45^{\circ} \mathrm{C}$. (Table 1).

Fruit extraction for antioxidant activity and phenolic analysis

Approximately $16 \mathrm{~g}$ of each blueberry sample was added to an equal volume $(40 \mathrm{~mL})$ of $99 \%$ methanol and homogenized in a blender for 3 minutes. The mixture was continuously stirred with a shaker (Heidolph Promax 2020, Schwabach, Germany) at room temperature for $24 \mathrm{~h}$. Particles were removed with filter paper. The final volume of the solution was adjusted with methanol. The methanolic extract was divided into two parts, the first being used for antioxidant tests and the second for phenolic analysis with HPLC. The liquid-liquid extraction procedure was applied to the second part for phenolic extraction. For each berry sample extract (prepared in methanol), $100 \mathrm{mg}$ of the sample was dipped in $\mathrm{pH} 2.0 \pm 0.1$ water and shaken vigorously followed by extraction with diethyl ether and ethyl acetate $(3 \times 5 \mathrm{~mL}$ each). Organic phases were combined evaporated and made up in methanol $(2.0 \mathrm{~mL})$ for HPLC after passing through filter $45 \mu$ size.

\section{Fruit extraction for sugars}

Fruit extractions were carried out according to the method described by (Kafkas et al., 2006) with some modifications. Fruit samples were dried in an oven at $45^{\circ} \mathrm{C}$ for one week. Dried samples were powdered by a crusher and approximately $1 \mathrm{~g}$ of each sample was weighed. Powdered fruit samples were transferred to a screw cap Eppendorf tube with $20 \mathrm{~mL}$ of aqueous ethanol $(80 \% \mathrm{v} / \mathrm{v})$. A reaction mixture was placed in a shaker and shaken at room temperature for $24 \mathrm{~h} / 200 \mathrm{rpm}$. Particles were removed with filter paper and liquid part evaporated to dryness with evaporator. The residue was dissolved with 2 $\mathrm{ml}$ of distilled water and filtered before HPLC analysis. 
Table 1. List of blueberry sampling place, collected year and cultivar

\begin{tabular}{|c|c|c|c|}
\hline Year & Place & Type & Cultivar \\
\hline 2014 & Giresun-Bulancak & NHB & Sunshine \\
\hline 2014 & Giresun-Bulancak & $\mathrm{NHB}$ & Northland \\
\hline 2014 & Giresun-Bulancak & SHB & Ozarkblue \\
\hline 2014 & Giresun-Bulancak & SHB & Misty \\
\hline 2014 & Giresun-Bulancak & $\mathrm{NHB}$ & Bluegold \\
\hline 2014 & Giresun-Bulancak & NHB & Sunrise \\
\hline 2014 & Giresun-Bulancak & SHB & Jubile \\
\hline 2012 & Rize-Handüzü & $\mathrm{N}$ & Vaccinium arctostaplylos \\
\hline 2012 & Rize-Handüzü & $\mathrm{N}$ & Vaccinium myrtillus \\
\hline 2014 & Trabzon-Hayrat & NHB & Brigitta \\
\hline 2014 & Trabzon-Kaşüstü & NHB & Duke \\
\hline 2014 & Giresun-Bulancak & SHB & Oneil \\
\hline 2014 & Giresun-Bulancak & $\mathrm{NHB}$ & Darrow \\
\hline 2014 & Trabzon-Kaşüstü & NHB & Torro \\
\hline 2014 & Trabzon-Kaşüstü & NHB & Herbert \\
\hline 2014 & Giresun-Bulancak & NHB & Brigitta \\
\hline 2014 & Giresun-Bulancak & $\mathrm{NHB}$ & Chandler \\
\hline 2014 & Trabzon-Kaşüstü & NHB & Blueray \\
\hline 2014 & Trabzon-Hayrat & $\mathrm{NHB}$ & Jersey \\
\hline 2014 & Trabzon-Hayrat & NHB & Bluecrop \\
\hline 2012 & Rize & NHB & Earlyblue \\
\hline 2014 & Trabzon-Hayrat & $\mathrm{NHB}$ & Bluegold \\
\hline 2014 & Trabzon-Kaşüstü & NHB & Putte \\
\hline 2014 & Trabzon-Kaşüstü & $\mathrm{NHB}$ & Berkeley \\
\hline 2014 & Trabzon-Hayrat & NHB & Torro \\
\hline 2014 & Trabzon-Kaşüstü & NHB & Patriot \\
\hline 2014 & Trabzon-Kaşüstü & $\mathrm{NHB}$ & Bluejay \\
\hline 2014 & Giresun-Bulancak & $\mathrm{NHB}$ & Bluejay \\
\hline 2014 & Giresun-Bulancak & $\mathrm{NHB}$ & Bluecrop \\
\hline 2014 & Trabzon-Kaşüstü & $\mathrm{NHB}$ & Spartan \\
\hline 2014 & Trabzon-Kaşüstü & NHB & Puru Sampling \\
\hline 2013 & Rize-Handüzü & $\mathrm{N}$ & Vaccinium arctostaplylos \\
\hline 2013 & Rize-Handüzü & $\mathrm{N}$ & Vaccinium myrtillus \\
\hline 2014 & Trabzon-Kaşüstü & $\mathrm{NHB}$ & Legassi \\
\hline 2014 & Trabzon-Kaşüstü & $\mathrm{HH}$ & Northcountry \\
\hline
\end{tabular}

\section{Determination of total phenolic contents (TPC)}

TPC's of methanolic extracts were determined with a method previously used and reported by Folin-Ciocalteu (Singleton et al., 1999). Briefly, $750 \mu \mathrm{L}$ of FolinCiocalteu's/water mixture (1:14) was added to a $50 \mu \mathrm{L}$ sample and after $3 \min 200 \mu \mathrm{L}$ of $20 \% \mathrm{Na}_{2} \mathrm{CO}_{3}$ was added. Then the reaction mixture was incubated in the dark for 30 min. The absorbance was measured on an ultraviolet-visible (UV-Vis) spectrophotometer (Unicam UV2-100) at 760 $\mathrm{nm}$ and methanol was used as blank. Gallic acid was used as a standard and total phenol contents in extracts were calculated as mg gallic acid equivalent total phenolic in $\mathrm{mg}$ Gallic Acid Equivalent/100 g (mg GAE /100 g) dry weight of plant.

\section{Determination of total flavonoid content (TFC)}

The total amount of flavonoid was measured using the spectrophotometric method at $430 \mathrm{~nm}$ as reported previously (Lamaison and Carnart, 1991). Stock solutions of each extract were prepared in methanol $(4 \mathrm{mg} / \mathrm{ml})$. A 1.5 $\mathrm{ml}$ of a $2 \%$ methanol solution of $\mathrm{AlCl}_{3} \cdot 6 \mathrm{H}_{2} \mathrm{O}$ was added to $0.5 \mathrm{ml}$ of the sample, then the sealed bottles were kept in the dark for $10 \mathrm{~min}$. The absorbance was read at $430 \mathrm{~nm}$, methanol $\mathrm{AlCl}_{3}$ used as blank, each measure in triplicated. A series of dilutions of quercetin in methanol was prepared and assayed; flavonoid amounts in the extract were expressed as $\mathrm{mg}$ quercetin equivalent flavonoid in $\mathrm{mg}$ quercetin Equivalent/100 (mg QAE /100 g) dry matter.

\section{Determination of anthocyanin content (TAC)}

Stock solutions of each extract were prepared in methanol $(6 \mathrm{mg} / \mathrm{ml})$. Two $40 \mu \mathrm{L}$ portions of the methanol stock solution were put into the test tubes and nine hundred and sixty microliters of $\mathrm{pH} 1.0(25 \mathrm{ml}$ of $1.49 \%$ $\mathrm{KCL}+67 \mathrm{ml}$ of $1.7 \% \mathrm{HCl}, \mathrm{pH}$ corrected with $\mathrm{HCl}$ ) or $\mathrm{pH}$ $4.5(1.64 \% \mathrm{AcONa}, \mathrm{pH}$ corrected with $\mathrm{AcOH})$ buffer solutions were added. The absorbance was read at 700 and $510 \mathrm{~nm}$ against blank for both $\mathrm{pH}$ values. Each experiment 
was carried out in triplicates and the total anthocyanin content was calculated from the following equation (Giusti and Wrolstad, 2001).

$\Delta \mathrm{A}=\left[\left(\mathrm{A}_{510 \mathrm{~nm}}-\mathrm{A}_{700 \mathrm{~nm}}\right)\right]_{\mathrm{pH}=1.0}-\left[\left(\mathrm{A}_{510 \mathrm{~nm}}-\mathrm{A}_{700 \mathrm{~nm}}\right)\right]_{\mathrm{pH}=4.5}$

$\mathrm{TACY}=(\Delta \mathrm{A} \times \mathrm{MW}$ × DF $\times 1000) / \varepsilon) \times 0.1$

TACY $=$ total anthocyanins expressed as mg cyanidin 3glucoside/100g sample $\mathrm{g} / \mathrm{L})$.

MW = molecular weight of cyanidin 3-glucoside (449.2

$\mathrm{DF}=$ dilution factor to express the samples on a per gram of plant

1000 is the conversion factor for grams to $\mathrm{mg}$.

$\varepsilon=$ molar absorbance coefficient of cyanidin 3-glucoside $\left(26,900 \mathrm{~L} \mathrm{M}^{-1} \mathrm{~cm}^{-1}\right)$.

0.1 is the conversion factor for per 1000 grams to 100 gram basis.

\section{Antioxidant activity assays}

DPPH antioxidant activity has become a general test method, because of rapid, simple and independent of sample polarity for measurement of free radical scavenging ability of plant extracts. The DPPH free radical scavenging activity of the extract was determined by a previously reported method (Kartal et al., 2007). The scavenging of 2,2-diphenyl-1-picrylhydrazyl (DPPH) radical was used to determine the radical scavenging activity of the methanolic blueberry samples. The colorimetric test was assayed using the Molyneux method. DPPH radical has a purple colour which decays in the presence of antioxidant agents, thus the change of the absorbance is monitored at $517 \mathrm{~nm}$. Tests were conducted in triplicates and butylated hydroxyl toluene (BHT) was used as a positive control.

\section{$\beta$-carotene-linoleic acid inbibition activity}

The $\beta$-carotene-linoleic acid inhibition activity of the extract was determined using a previously reported method (Huang et al., 2005). Briefly, $0.5 \mathrm{mg} \beta$-carotene was dissolved in $1 \mathrm{~mL}$ chloroform then $25 \mu \mathrm{L}$ linoleic acid and $200 \mathrm{mg}$ Tween 40 were added to this and mixed vigorously. The chloroform was then evaporated under reduced pressure on a rotary evaporator and $100 \mathrm{ml}$ of oxygenated distilled water was subsequently added to the residue and mixed gently to form a clear yellowish emulsion. The 350 $\mu \mathrm{L}$ of extract $(2 \mathrm{mg} / \mathrm{mL}$ in ethanol) was placed into a test tube and $2.5 \mathrm{~mL}$ of $\beta$-carotene-linoleic acid mixture was added to this and mixed thoroughly. The mixture was incubated at room temperature for 24 hours and then the absorbance was measured at $490 \mathrm{~nm}$ on an ultravioletvisible (UV-vis) spectrometer. BHT was used as a positive control and for a negative control (blank) the same volume of ethanol was used instead of the extract. Reading of blank was taken before and after the 24 hour incubation process and the absorbance value was subtracted from all samples. Relative antioxidant activity (RAA \%) of the extract was calculated using the following equation:

$$
\text { RAA\% }=\frac{\text { A zample }}{\text { A BHT }} \times 100
$$

\section{FRAP (Reducing Ability) Assay}

The measure of extract to reduce the ferric tripyridyltriazine ( $\left.\mathrm{Fe}^{3+-} \mathrm{TPTZ}\right)$ complex is also considered as an antioxidant activity. The assay protocol was carried out according to the methods described by Benzie and Strain (2005), with some modifications. The test involves the reduction of ferric tripyridyltriazine $\left(\mathrm{Fe}^{3+}\right.$-TPTZ) complex to a blue colored Fe (II) TPTZ by antioxidant constituents of extracts. Working ferric reducing/antioxidant power (FRAP) reagent was prepared by mixing (10:1:1) of 300 $\mathrm{mM}$ acetate buffer ( $\mathrm{pH} 3.6$ ) with of $10 \mathrm{mM}$ TPTZ solution in $40 \mathrm{mM} \mathrm{HCl}$ and $20 \mathrm{mM} \mathrm{FeCl}_{3} .6 \mathrm{H}_{2} \mathrm{O}$ solution. $3 \mathrm{~mL}$ of the freshly prepared FRAP reagent and $100 \mu \mathrm{L}$ of the samples were mixed and incubated for $4 \mathrm{~min}$ at $37^{\circ} \mathrm{C}$ and the absorbance was noted at $595 \mathrm{~nm}$ against reagent blank containing distilled water. Trolox was used a positive control to construct a reference curve $(62.5-1000 \mathrm{mg} / \mathrm{L})$, FRAP values were expressed as mg Trolox Equivalent/100g (mg TE/100 g).

\section{Analysis of phenolic compounds by HPLC}

Seventeen standards of phenolic compounds were analysed using HPLC (Fig. 1). HPLC-DAD analysis of biomass methanol extract was performed according to the method described by Hatipoğlu et al. (2013), with some changes in the gradient flow of the mobile phase. The HPLC-DAD system (Agilent Technology, 1260 infinity) consisted of quaternary pumps (1260 QUAT pump VL) and an auto injector (model $1260 \mathrm{ALS}$ ) connected to a DAD (diode array detector) (1260 DAD VL). An AC-18 reverse phase column $(250 \mathrm{~mm} \times 4.6 \mathrm{~mm}$ id, $5 \mu \mathrm{m}$ particle sizes, HICHROM, UK) was used for the analysis which was fixed in the column oven (1260 TCC). The mobile phase was a mixture of solvent $\mathrm{A}(2 \% \mathrm{AcOH}$ in water) and solvent B (70:30, acetonitrile/water) which was sonicated before stirring and continuously degassed by the built-in HPLC system. The injection volume was $20 \mu \mathrm{L}$ and the column was kept at $30{ }^{\circ} \mathrm{C}$. The calibration curves for quantification were obtained by running reference standards in the range of 1.5 to $25 \mathrm{ppm}$ and the regression for all phenolics was found $\geq 0.999$. The flow rate was kept constant at $1 \mathrm{~mL} \mathrm{m^{-1 }}$ using gradient programming; starting the flow of mobile phase as B (5\%) to three minutes, gradually increasing (up-to $15,20,25,40$ and $80 \%$ at $8,10,18,25$ and 35 minutes respectively) and decreasing to $5 \%$ at 40 minutes and left for 10 minutes to equilibrate in the column. The eluent was continuously monitored through PDA by measuring at three different wave lengths i.e. 280,315 and $350 \mathrm{~nm}$.

\section{Analysis of sugar compounds by HPLC}

Ten standards of sugar compounds were analyzed using HPLC-RID (Fig. 2). The liquid chromatographic apparatus shows the same features with phenolic analysed using HPLC. Refractive index detector is used for sugar analysis as distinct from phenolic analysis. Separations were performed on a reverse-phase Nucleosil $\mathrm{NH}_{2}$ analytical column operating at room temperature with a flow rate of 1 $\mathrm{mL} \min ^{-1}$. The sample injection volume was $20 \mu \mathrm{L}$. The calibration curves for quantification were obtained by running reference standards in the range of 1.5 to $25 \mathrm{ppm}$ and the regression for all phenolics was $\geq 0.999$. Elution was effected using an isocratic elution of $79 \%$ aqueous acetonitrile as a solvent. Compounds were identified by comparing their retention times. 10 min equilibrium time was allowed between injections. 


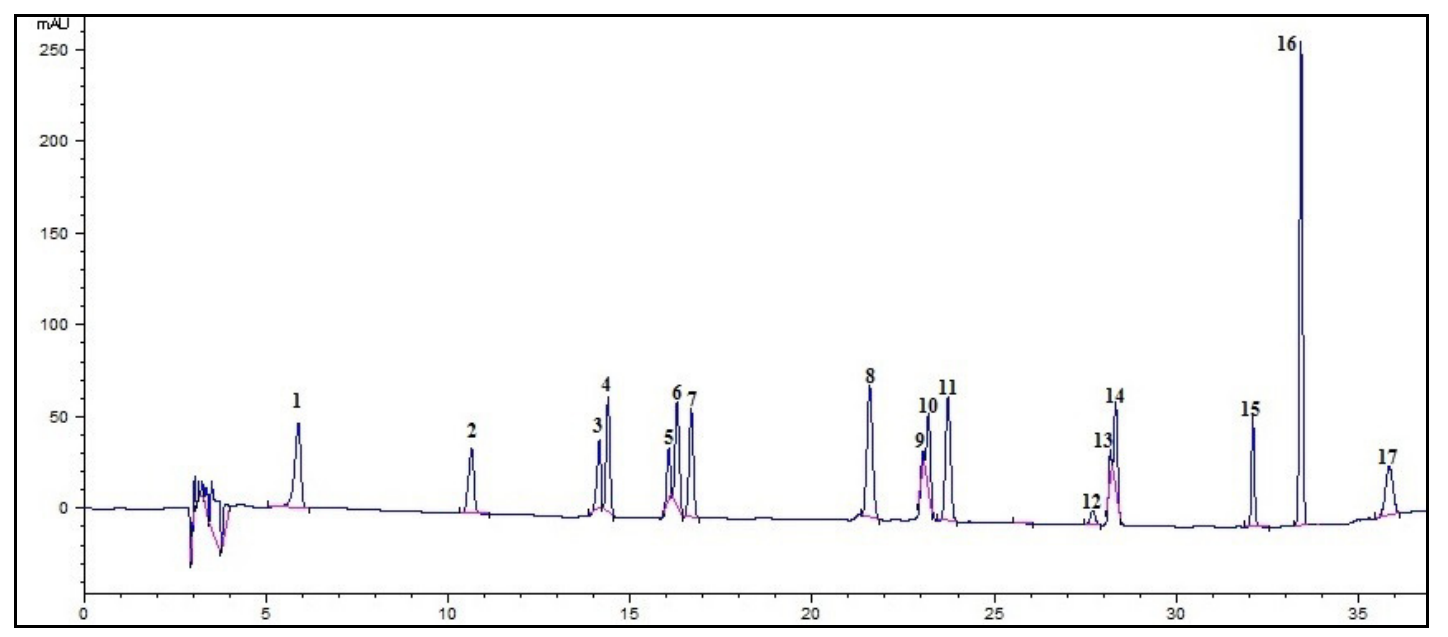

Fig. 1. HPLC-DAD chromatograms of the Phenolic Standards $(280 \mathrm{~nm}$ ) (1) Gallic acid, (2) Protocatechuic acid, (3) Chlorogenic acid, (4) p-OH benzoic acid, (5) Vanilic acid, (6) Kaffeic acid, (7) Syringic acid, (8) Ferulic acid, (9) Ellagic acid, (10) Rutin, (11) p-Kumaric acid, (12) Benzoic acid, (13) Rosmarinic acid, (14) o-cumaric acid (15) quercetin, (16)t-cinnamic acid, (17) Curcumin

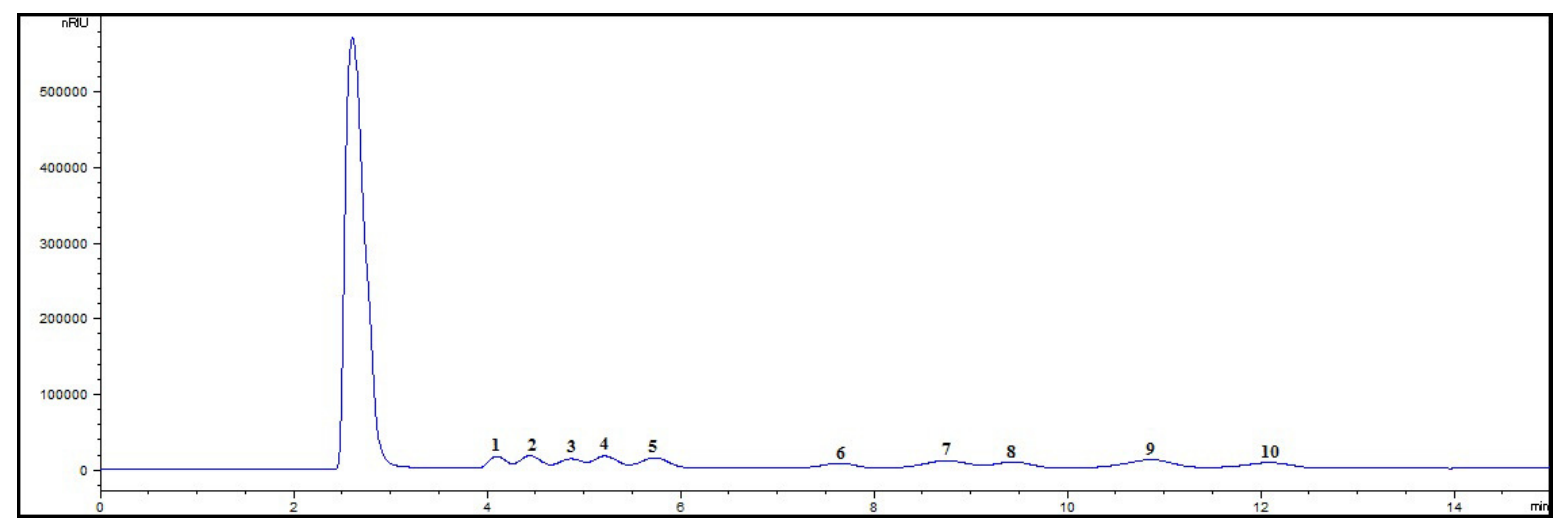

Fig. 2. HPLC-RID chromatography of sugar standards (1) Ribose, (2) Arabinose, (3) Fructose, (4) Glucose, (5)Galactose, (6)Sucrose, (7) Maltose, (8) Trehalose, (9) Melibiose, (10) Melezitose

\section{Statistical analysis}

Correlations and ' $t$ ' tests were performed using SPSS 13.0. The regression and correlation analysis were performed with Kruskal-Wallis and the Pearson correlation analysis as a non-parametric test. The significance was set at $\mathrm{p}<0.01$. In the interpretation of the results according to the correlation, $\mathrm{r}<0.2$ was assessed as a very weak correlation or no correlation at all, 0.2-0.4 as a weak correlation, 0.4-0.6 as a medium correlation, $0.6-0.8$ as a high correlation and $0.8>$ as a very high correlation.

\section{Results and Discussion}

Total phenolic, flavonoids and anthocyanin content

The comparative results regarding the total phenolic content (TPC), total flavonoids content (TFC) and total anthocyanin's content (TAC) in wild and cultivated blueberries are given in Table 2 .

TPC is marker of blueberry antioxidant capacity and is generally used as an antioxidant test. The amount of TPC changed from $76.20 \mathrm{mg}$ GAE/100 g to $215.12 \mathrm{mg}$ GAE/100 g also these values were found statistically significant. The total phenolic content in wild species of blueberries was found to be higher than that in cultivar berries. Similar results were reported by Koca and Karadeniz (2009), on $V$. arctostaphylos samples: these authors reported total phenolic concentrations ranging from 308-542 $\mathrm{mg} / 100 \mathrm{~g}$ in $V$. arctostaphylos, and a total phenolic content ranging from $77-140 \mathrm{mg} / 100 \mathrm{~g}$ in berries ('Rekord', 'Northland', 'Ivanhoe'). Lee et al. (2004), also studied the TPC of wild Vaccinium species as compared to cultivated ones. The authors reported that the total phenolic content of wild Vaccinium species varied from 489 to $702 \mathrm{mg} / 100 \mathrm{~g}$, while cultivated $V$. membranaceum total phenolic concentrations ranged from 225 to $423 \mathrm{mg} / 100 \mathrm{~g}$. Among the cultivated berries, 'Bluejay' (Bulancak) had the highest TPC at $213.82 \mathrm{mg} \mathrm{GAE} / 100 \mathrm{~g}$, while the lowest value was found for the 'Toro' (Hayrat) variety (76.20 mg GAE/100 g). The difference observed in TPC can be attributed to the different locations as well as the fact that synthesis phenolic compounds are affected by various abiotic and biotic factors, including temperature, irradiation, herbivory, and pathogenic infection (Kalt et al., 2001). The TPC data obtained are comparable to previous findings which reported values between 251-310 mg GAE/100 g for cultivated blueberries and 577-614 $\mathrm{mg}$ GAE/100 $\mathrm{g}$ for wild Italian blueberries (Giovanelli and Buratti, 2009). Ehlenfeldt and Prior (2001), reported a higher TPC value 
644

Table 2. Total polyphenols, total flavonoids and total anthocyanin content in blueberries

\begin{tabular}{|c|c|c|c|}
\hline Sample Name & $\begin{array}{c}\text { TPC } \\
(\mathrm{mg} \mathrm{GAE} / 100 \mathrm{~g})\end{array}$ & $\begin{array}{c}\text { TFC } \\
(\mathrm{mg} \mathrm{QE} / 100 \mathrm{~g})\end{array}$ & $\begin{array}{c}\text { TAC } \\
(\mathrm{mg} \mathrm{c} 3-\mathrm{GE} / 100 \mathrm{~g})\end{array}$ \\
\hline Berkeley (Kaşüstü) & $140.95 \pm 5.92^{\mathrm{mn}}$ & $48.64 \pm 4.33^{\mathrm{d}}$ & $93.50 \pm 7.41^{j}$ \\
\hline Bluecrop (Bulancak) & $83.23 \pm 1.09^{\mathrm{ab}}$ & $40.36 \pm 2.07^{\mathrm{c}}$ & $44.97 \pm 0.56^{c}$ \\
\hline Bluecrop (Rize) & $123.51 \pm 3.793^{\mathrm{jk}}$ & $59.34 \pm 1.36^{\mathrm{f}}$ & $55.97 \pm 1.48^{d}$ \\
\hline Bluegold (Bulancak) & $105.57 \pm 4.27^{\mathrm{def}}$ & $87.55 \pm 8.31^{k}$ & $245.89 \pm 1.48^{\mathrm{t}}$ \\
\hline Bluegold (Hayrat) & $164.04 \pm 11.90^{\mathrm{oP}}$ & $84.01 \pm 1.81^{k}$ & $255.92 \pm 8.08^{u}$ \\
\hline Bluejay (Bulancak) & $213.82 \pm 5.34^{v}$ & $57.27 \pm 0.51^{\text {ef }}$ & $127.79 \pm 1.12^{\mathrm{mn}}$ \\
\hline Bluejay (Kaşüstü) & $171.42 \pm 3.24^{\mathrm{pr}}$ & $58.05 \pm 1.18^{f}$ & $156.91 \pm 0.56^{\mathrm{P}}$ \\
\hline Blueray (Kaşüstü) & $118.68 \pm 2.37^{\text {ghij }}$ & $40.02 \pm 0.79^{c}$ & $74.41 \pm 1.48^{\mathrm{fg}}$ \\
\hline Brigitta (Bulancak) & $134.75 \pm 11.29^{\mathrm{m}}$ & $41.65 \pm 0.79^{c}$ & $86.06 \pm 0.56^{h i j}$ \\
\hline Brigitta (Hayrat) & $97.35 \pm 6.66^{\mathrm{cd}}$ & $37.08 \pm 1.44^{\mathrm{bc}}$ & $67.29 \pm 0.56^{\text {ef }}$ \\
\hline Chandler (Bulancak) & $111.98 \pm 1.34^{\text {fghi }}$ & $30.44 \pm 0.90^{\mathrm{a}}$ & $72.47 \pm 1.48^{\mathrm{fg}}$ \\
\hline Darrow (Bulancak) & $111.03 \pm 1.60^{\mathrm{efg}}$ & $41.22 \pm 1.61^{\mathrm{c}}$ & $111.29 \pm 2.96^{k}$ \\
\hline Duke (Kaşüstü) & $178.55 \pm 13.04^{\text {rs }}$ & $59.60 \pm 0.89^{f}$ & $160.79 \pm 4.58^{\mathrm{P}}$ \\
\hline Early Blue (Rize) & $124.24 \pm 10.38^{\mathrm{jkl}}$ & $55.37 \pm 1.16^{\text {ef }}$ & $83.47 \pm 0.97^{\text {hi }}$ \\
\hline Herbert (Kaşüstü) & $170.57 \pm 1.36^{\mathrm{pr}}$ & $52.61 \pm 0.93^{\mathrm{de}}$ & $147.85 \pm 2.96^{\circ}$ \\
\hline Jersey (Hayrat) & $123.50 \pm 6.94^{\text {ijkl }}$ & $53.13 \pm 0.93^{\text {de }}$ & $119.06 \pm 1.12^{1}$ \\
\hline Jubile (Bulancak) & $131.48 \pm 2.20^{\mathrm{jklm}}$ & $52.61 \pm 1.18^{\mathrm{de}}$ & $78.29 \pm 1.12^{\mathrm{gh}}$ \\
\hline Legassi (Kaşüstü) & $77.26 \pm 1.99^{a}$ & $55.37 \pm 1.07^{\mathrm{ze}^{\mathrm{f}}}$ & $90.59 \pm 4.37^{\mathrm{ij}}$ \\
\hline Misty (Bulancak) & $135.32 \pm 3.81^{\mathrm{mn}}$ & $48.82 \pm 1.27^{\mathrm{d}}$ & $22.32 \pm 3.36^{a}$ \\
\hline Northcountry(Kaşüstü) & $92.06 \pm 1.30^{\mathrm{bc}}$ & $72.45 \pm 3.08^{\text {hi }}$ & $226.47 \pm 6.18^{s}$ \\
\hline Northland (Bulancak) & $132.97 \pm 5.54^{\mathrm{lm}}$ & $49.25 \pm 1.18^{\mathrm{d}}$ & $83.79 \pm 6.60^{\mathrm{hi}}$ \\
\hline Oneil (Bulancak) & $101.00 \pm 1.35^{\text {cde }}$ & $64.69 \pm 1.72^{\mathrm{g}}$ & $61.14 \pm 7.76^{\mathrm{de}}$ \\
\hline Ozarkblue (Bulancak) & $157.24 \pm 4.25^{\circ}$ & $77.72 \pm 3.13^{j}$ & $159.18 \pm 0.1^{P}$ \\
\hline Patriot (Kaşüstü) & $118.38 \pm 2.84^{\text {ghij }}$ & $40.02 \pm 0.53^{c}$ & $74.41 \pm 2.96^{\text {fg }}$ \\
\hline Puru (Kaşüstü) & $121.83 \pm 9.48^{\mathrm{jk}}$ & $37.00 \pm 0.59^{\mathrm{bc}}$ & $35.25 \pm 2.24^{b}$ \\
\hline Putte Sampling & $170.46 \pm 10.04^{\mathrm{pr}}$ & $69.52 \pm 0.83^{\mathrm{h}}$ & $125.53 \pm 3.12^{\operatorname{lm}}$ \\
\hline Spartan (Kaşüstü) & $186.51 \pm 5.15^{\mathrm{st}}$ & $56.32 \pm 1.22^{e^{e f}}$ & $188.94 \pm 3.67^{\mathrm{r}}$ \\
\hline Sunrise (Bulancak) & $120.48 \pm 1.44^{\text {hij }}$ & $34.49 \pm 2.46^{b}$ & $43.03 \pm 2.02^{c}$ \\
\hline Sunshine (Bulancak) & $120.63 \pm 1.73^{\text {hij }}$ & $55.80 \pm 6.21^{\mathrm{ef}}$ & $85.09 \pm 0.56^{\text {hi }}$ \\
\hline Toro (Hayrat) & $76.20 \pm 0.66^{a}$ & $56.58 \pm 3.06^{\text {ef }}$ & $55.02 \pm 3.12^{d}$ \\
\hline Toro (Kaşüstü) & $108.65 \pm 1.92^{\text {efg }}$ & $40.45 \pm 1.18^{c}$ & $87.35 \pm 2.56^{i 1}$ \\
\hline V. arctostaplylos (2012) & $181.35 \pm 5.50^{\mathrm{s}}$ & $91.69 \pm 1.12^{1}$ & $295.06 \pm 17.47^{y}$ \\
\hline V. arctostaplylos (2013) & $193.19 \pm 3.09^{\text {tu }}$ & $76.34 \pm 1.07^{\mathrm{ij}}$ & $280.51 \pm 5.13^{v}$ \\
\hline V. myrtillus (2012) & $199.87 \pm 2.28^{u}$ & $76.77 \pm 2.64^{j}$ & $230.68 \pm 2.80^{\mathrm{s}}$ \\
\hline V. myrtillus (2013) & $215.12 \pm 1.30^{v}$ & $77.80 \pm 3.25^{j}$ & $223.89 \pm 2.96^{\mathrm{s}}$ \\
\hline
\end{tabular}

for 'Berkeley', 'Bluecrop', 'Bluegold', 'Bluejay', 'Brigitta', 'Chandler', 'Duke', 'Earlyblue', 'Herbert', 'Jubile', 'Misty', 'Patriot', 'Puru', 'Spartan', 'Toro' and 'Sunshine' than the the TPC values found for blueberries in our study. The differences in the reported data partially result from varied analytical methods (especially the extraction step) employed by the authors. Similar results, 115.0 and $4.2 \mathrm{mg} \mathrm{GAE} / 100$ $\mathrm{g}$ for $V$. corymbosum berries in ethanol and water extract, were obtained by Smad et al. (2014).

Flavonoids constitute the largest subgroup of the polyphenols, having more than 8,000 compounds in this group. Flavonoids are responsible for antioxidant activity (Pietta $e$ t al., 2003). In the examination of TFC amounts of the blueberries (Table 2) are determined to have the highest value in $V$. arctostaplylos with $91.69 \mathrm{mg} \mathrm{QE} / 100 \mathrm{~g}$ (2011) and the lowest value in the 'Chandler' variety with $30.44 \mathrm{mg}$ $\mathrm{QE} / 100 \mathrm{~g}$. The highest value among the cultivars in the 'Bluegold' variety was found in berries collected from the
Bulancak region. Furthermore, there was no statististical difference in regards to their contents for 'Bluegold', 'Bluejay', 'Brigitta' and 'Toro' among berries of the same variety but collected from different regions with the exception of 'Bluecrop'. The total flavonoid contents of natural berries were determined to be relatively higher compared with cultivars. In another study, natural (V. myrtillus) and cultivar ('Elliot', 'Bluecrop' and 'Duke') blueberries were examined, the TFC amounts were reported to vary between $84.33-112.5 \mathrm{mg} \mathrm{QE} / 100 \mathrm{~g}$. Moreover, the TFC amount in natural berries was much higher than the TFC amount in cultivar varieties (Bunea $e t$ al., 2011). It was reported in another study performed by Marinova et al. (2005), that the TFC amount of the variety V. myrtillus was $190.3 \mathrm{mg} \mathrm{CE} / 100 \mathrm{~g}$ (Marinova et al., 2005). In the other study, the TPC amounts of 1997,1998 , 1999 of the fruits of the varieties $V$. myrtillus, $V$.uligonosum and $V$. vitis-idea in the regions Orimattila, Mantyharju, 
Nurmes are examined, it is reported that there are some differences determined with regards to the TPC contents of blueberries in natural form grown in different regions of Finland. This difference is particularly significant in regards to the TFC amounts (Kahkönen et al., 2001). In addition, a study conducted in northwest Croatia in 2006 and 2007 examined the TFC amounts of 'Duke', 'Elliott', 'Sierra' and 'Bluecrop' berries. The study concluded that the TFC amounts of the cultivar varieties in 2006 and 2007 for 'Duke' were between 268.97 and $216.87 \mathrm{mg} \mathrm{RE} / 100 \mathrm{~g}$, between 376.68 and $255.33 \mathrm{mg} \mathrm{RE} / 100 \mathrm{~g}$ for 'Eliott', between 528.15 and $331.34 \mathrm{mg} \mathrm{RE} / 100 \mathrm{~g}$ for 'Sierra', and between 368.33 and $291.56 \mathrm{mg} \mathrm{RE} / 100 \mathrm{~g}$ for 'Bluecrop'. Therefore, this study demonstrates that there are differences between TFC values of cultivar blueberries obtained from the same region during different years. The authors explained that this difference is attributed to changes in the climate in between seasons. Also, researchers argue that particularly high temperatures significantly influence amount of TFC (Uzelac et al., 2010). A large amount of literature illustrates that the TFC amounts of the same blueberry can be different. In addition to differences in climatic conditions, there are many variables such as methodological differences at the performed studies or cultivation techniques that may have caused this. (Häkkinen and Törrönen, 2000; Kahkönen et al., 2001; Koca and Karadeniz, 2009).

There are 16 different types of anthocyanins responsible for the colouring of blueberries. It is reported as a result of the performed clinic studies that these anthocyanin's significantly increase the night vision (Kalt and Dufor, 1997). The total anthocyanin content (TAC) for blueberries is indicated in Table 2. In the performed study the TAC amount of blueberries varied between 22.32$295.06 \mathrm{mg} c 3-\mathrm{GE} / 100 \mathrm{~g}$. It was determined that the TAC amounts in natural blueberries were higher than that in most of the cultivar berries. The highest TAC amount is determined in $V$. arctostaplylos (2012) among the natural varieties and with $255.92 \mathrm{mg}$ c3-GE/100 g in the 'Bluegold' (Hayrat) variety among the cultivar varieties. According to literature, the TAC amounts of blueberries vary between 25-497 mg c3-GE/100 g (Ragvendra et al., 2011). The TAC amounts in our study are similar with those in the literature. Previous study about the phenolic compounds of the $V$. myrtillus and 8 different cultivar varieties reported that the TAC amounts of the $V$. myrtillus are higher than those of the other cultivar. They have reported in the same study that the TAC amount for the $V$. myrtillus is $3.70 \mathrm{mg}$ malvidin-3-glucoside/g. The TAC amounts for 'Blomidon', 'Cumberland', 'Fundy', 'Bluecrop', 'Coville' and 'Jersey' were found to be $0.954,1.53,2.55,0.832,0.998$ and 1.17 mg malvidin-3-glucoside/g respectively (Kalt and Dufor, 1997). It was also reported in another study in which eighty seven different blueberry types were examined that the TAC amounts varied between 89-331 mg c3-GE/100 g. The TAC amounts of 'Bluegold', 'Bluejay', 'Legasi', 'Ozarkblue' and 'Spartan' were found to be similar, 'Berkeley', 'Bluecrop', 'Blueray', 'Brigitta', 'Chandler', 'Darrow', 'Duke', 'Earlyblue', 'Herbert', 'Jersey', 'Jubile', 'Legassi', 'Misty', 'Northland', 'Oneil', 'Sunrise', 'Sunshine', 'Patriot', 'Puru' and 'Toro' were found lower than in a previous study (Ehlenfeldt and Prior, 2001). Furthermore, in another study conducted on natural and cultivar varieties in Turkey, the total anthocyanin amounts of blueberry fruits were determined to be between $59-294 \mathrm{mg}$ c3$\mathrm{GE} / 100 \mathrm{~g}$ for $V$. arctostaphylos. In addition, the same study reported the total anthocyanin amounts in 'Jersey', 'Ivanhoe', 'Northland' and 'Record' as $25 \mathrm{mg}$ c3-GE/100 g for 'Jersey' and 'Ivanhoe', $29 \mathrm{mg}$ c3-GE/100 g for 'Northland' and 0,18 mg c3-GE/100 g for 'Record' (Koca and Karadeniz, 2009). Compared with in this study, the TAC amounts of the natural $V$. arctostaphylos berries were found to be quite higher than those of the cultivar forms in the literature, too. In this regard, this study is consistent with the literature. However, there were some instances in which the total anthocyanin amounts for the blueberries were found to be less or much higher than values in the literature. These differences may be due to the fact that anthocyanin synthesis is influenced by environmental biotic and abiotic factors in addition to genotype or different growth conditions (Kalt et al., 2000; Koca and Karadeniz, 2009).

\section{Antioxidant activities of the blueberry fruits}

Molecules known as antioxidants prevent oxidation in living organisms by decreasing free radicals or by completely eliminate these (Can et al., 2015). There are many methods in order to measure the antioxidant capacity in natural products (Okan et al., 2013). To measure the antioxidant capacities of blueberries, this study used the Ferric Reducing Antioxidant Capacity (FRAP), the DPPH radical scavenging activity test and the Beta Carotene colour test ( $\beta$-carotene). High FRAP and $\beta$-carotene and low DPPH values indicate a high antioxidant capacity. Final measurements for the three different antioxidant methods (DPPH, FRAP, Beta Carotene) are indicated in Table 3.

Findings from the Table 3 illustrate that the highest antioxidant activity according to all three methods is seen in natural berries. The highest antioxidant activity according to all three methods among the cultivar berries was observed in 'Duke' and in $V$. myrtillus among the natural berries collected in 2013. The total antioxidant capacity values for blueberries for FRAP were found to be between 454.93$3632.96 \mu \mathrm{mol}$ troloks $/ 100 \mathrm{~g}$, for $\beta$-Carotene between 34.23 $86.48 \%$, and for DPPH between $1.01-4.78 \mathrm{mg} / \mathrm{mL}$. When all cultivar and natural berries are examined, it is seen that blueberries are an important antioxidant source. Prior $e t$ al. (1998), have examined the antioxidant capacities of natural and cultivar blueberries collected in the Oregon (OR), New Jersey (NJ) and Michigan (MI) according to the ORAC (Oxygen Radical Absorbance Capacity) method. The ORAC value of $V$. myrtillus was determined to be 44.6 $\mu \mathrm{mol} \mathrm{TE} / \mathrm{g}$ according to this study. The other values in this study were reported to be $17.0 \mu \mathrm{mol} T \mathrm{TE} / \mathrm{g}$ for 'Bluecrop', $18.1 \mu \mathrm{mol} \mathrm{TE} / \mathrm{g}$ for 'Jersey' (OR), $20.8 \mu \mathrm{mol} \mathrm{TE} / \mathrm{g}$ for 'Jersey' (MI) and $21.4 \mu \mathrm{mol}$ TE/g for 'Jersey' (NJ) cultivar varieties. Nevertheless, the ORAC capacity of 'Duke' was determined to be $25.1 \mu \mathrm{mol} \mathrm{TE} / \mathrm{g}$ and the ORAC capacity of 'O'Neil' was determined to be $16.8 \mu \mathrm{mol}$ TE/g. From these values, it is seen that the antioxidant capacities of natural berries are much higher than those of cultivars. Furthermore, researchers have noted that regional differences can influence the antioxidant capacities of blueberries of the same variety (Prior et al., 1998). In a 
646

Table 3. Antioxidant activity for blueberry fruits using three different complementary assays (FRAP, DPPH, $\beta$-Carotene)

\begin{tabular}{|c|c|c|c|}
\hline Sample & $\begin{array}{c}\text { DPPH-SC } 50 \\
(\mathrm{mg} / \mathrm{mL})\end{array}$ & $\begin{array}{c}\text { FRAP } \\
(\mu \mathrm{mol} \text { troloks } / 100 \mathrm{~g})\end{array}$ & $\beta$-Carotene Linoleic Acid (\%) \\
\hline Berkeley (Kaşüstü) & $4.07 \pm 0.12^{\mathrm{km}}$ & $1140.73 \pm 15.28^{\text {gh }}$ & $66.40 \pm 2.78^{\mathrm{jkm}}$ \\
\hline Bluecrop (Bulancak) & $5.65 \pm 0.07^{\circ}$ & $771.03 \pm 18.85^{\mathrm{b}}$ & $40.66 \pm 2.48^{b}$ \\
\hline Bluecrop (Rize) & $4.08 \pm 0.01^{\mathrm{km}}$ & $454.93 \pm 5.58^{\mathrm{a}}$ & $66.41 \pm 0.77^{\mathrm{jkm}}$ \\
\hline Bluegold (Bulancak) & $3.39 \pm 0.05^{\mathrm{i}}$ & $1445.87 \pm 36.94^{\mathrm{kl}}$ & $64.63 \pm 0.77^{\mathrm{jik}}$ \\
\hline Bluegold (Hayrat) & $2.82 \pm 0.04^{\mathrm{gh}}$ & $1494.55 \pm 33.21^{\mathrm{lm}}$ & $65.89 \pm 2.35^{\mathrm{jkl}}$ \\
\hline Bluejay (Bulancak) & $2.61 \pm 0.04^{\mathrm{efg}}$ & $1960.16 \pm 33.74^{\mathrm{P}}$ & $61.51 \pm 6.24^{\text {hij }}$ \\
\hline Bluejay (Kašüstü) & $2.28 \pm 0.17^{\mathrm{d}}$ & $1814.20 \pm 60.09^{\circ}$ & $62.54 \pm 2.78^{\text {hijk }}$ \\
\hline Blueray (Kaşüstü) & $3.84 \pm 0.09^{\mathrm{jk}}$ & $985.79 \pm 13.89^{e}$ & $49.42 \pm 1.54^{\mathrm{e}}$ \\
\hline Brigitta (Bulancak) & $3.72 \pm 0.31^{j}$ & $1067.70 \pm 9.69^{\mathrm{fg}}$ & $51.48 \pm 3.21^{\text {ef }}$ \\
\hline Brigitta (Hayrat) & $3.92 \pm 0.4^{\mathrm{kl}}$ & $1189.74 \pm 23.33^{\mathrm{gh}}$ & $62.55 \pm 2.54^{\text {hijk }}$ \\
\hline Chandler (Bulancak) & $3.43 \pm 0.12^{\mathrm{i}}$ & $903.51 \pm 12.86^{\mathrm{cd}}$ & $46.59 \pm 3.65^{\mathrm{cde}}$ \\
\hline Darrow (Bulancak) & $2.75 \pm 0.11^{\mathrm{fgh}}$ & $1541.02 \pm 11.68^{\mathrm{mn}}$ & $39.38 \pm 3.09^{b}$ \\
\hline Duke (Kaşüstü) & $1.71 \pm 0.05^{\mathrm{c}}$ & $2245.15 \pm 125.14^{r}$ & $76.06 \pm 1.16^{\circ}$ \\
\hline Early Blue (Rize) & $4.22 \pm 0.08^{\mathrm{m}}$ & $954.46 \pm 24.12^{\text {de }}$ & $48.90 \pm 3.80^{\mathrm{de}}$ \\
\hline Herbert (Kaşüstü) & $2.56 \pm 0.18^{\text {ef }}$ & $1471.12 \pm 18.69^{\mathrm{klm}}$ & $70.52 \pm 3.48^{\mathrm{lmn}}$ \\
\hline Jersey (Hayrat) & $4.16 \pm 0.07^{\mathrm{lm}}$ & $1006.90 \pm 10.64^{\mathrm{ef}}$ & $59.97 \pm 1.61^{\text {ghi }}$ \\
\hline Jubile (Bulancak) & $3.34 \pm 0.22^{i}$ & $1324.99 \pm 15.49^{i}$ & $55.60 \pm 8.35^{\mathrm{fg}}$ \\
\hline Legassi (Kaşüstü) & $2.74 \pm 0.19^{\mathrm{fgh}}$ & $1099.17 \pm 33.22^{\mathrm{gh}}$ & $44.01 \pm 2.78^{\mathrm{bcd}}$ \\
\hline Misty (Bulancak) & $2.86 \pm 0.03^{\mathrm{h}}$ & $828.89 \pm 23.11^{\mathrm{bc}}$ & $66.92 \pm 1.94^{\mathrm{klm}}$ \\
\hline Northcountry(Kaşüstü) & $2.95 \pm 0.15^{\mathrm{h}}$ & $1336.77 \pm 40.77^{\mathrm{ij}}$ & $55.60 \pm 0.01^{\mathrm{fg}}$ \\
\hline Northland (Bulancak) & $3.45 \pm 0.02^{\mathrm{i}}$ & $1095.27 \pm 15.30^{\text {gh }}$ & $55.59 \pm 2.32^{\mathrm{fg}}$ \\
\hline Oneil (Bulancak) & $2.97 \pm 0.14^{\mathrm{h}}$ & $980.36 \pm 13.77^{\text {de }}$ & $34.23 \pm 4.65^{\mathrm{a}}$ \\
\hline Ozarkblue (Bulancak) & $2.56 \pm 0.07^{\mathrm{ef}}$ & $1274.26 \pm 28.72^{i}$ & $74.90 \pm 0.77^{\mathrm{no}}$ \\
\hline Patriot (Kaşüstü) & $4.78 \pm 0.05^{\mathrm{n}}$ & $1287.16 \pm 64.59^{\mathrm{i}}$ & $55.34 \pm 2.23^{\mathrm{fg}}$ \\
\hline Puru (Kaşüstü) & $2.97 \pm 0.07^{\mathrm{h}}$ & $1167.27 \pm 64.55^{\mathrm{h}}$ & $58.42 \pm 1.17^{\text {gh }}$ \\
\hline Putte Sampling & $2.80 \pm 0.08^{\mathrm{fgh}}$ & $1517.64 \pm 65.40^{\operatorname{lm}}$ & $67.18 \pm 0.77^{\mathrm{klm}}$ \\
\hline Spartan (Kaşüstü) & $2.21 \pm 0.11^{\mathrm{d}}$ & $1611.94 \pm 29.90^{\mathrm{n}}$ & $51.73 \pm 2.78^{\mathrm{ef}}$ \\
\hline Sunrise (Bulancak) & $2.40 \pm 0.05^{\mathrm{de}}$ & $1294.77 \pm 19.03^{\mathrm{i}}$ & $71.56 \pm 3.56^{\mathrm{mno}}$ \\
\hline Sunshine (Bulancak) & $3.27 \pm 0.04^{\mathrm{i}}$ & $1280.71 \pm 75.33^{\mathrm{i}}$ & $59.46 \pm 0.01^{\text {ghi }}$ \\
\hline Toro (Hayrat) & $3.94 \pm 0.21^{\mathrm{jkl}}$ & $1074.60 \pm 16.45^{\mathrm{fg}}$ & $39.63 \pm 5.47^{\mathrm{b}}$ \\
\hline Toro (Kaşüstü) & $4.23 \pm 0.16^{\mathrm{m}}$ & $935.93 \pm 67.78^{\text {de }}$ & $55.60 \pm 2.32^{\mathrm{fg}}$ \\
\hline V. arctostaplylos (2012) & $1.52 \pm 0.02^{\mathrm{bc}}$ & $2194.36 \pm 25.04^{r}$ & $71.81 \pm 2.04^{\mathrm{mno}}$ \\
\hline V. arctostaplylos (2013) & $1.10 \pm 0.04^{\mathrm{a}}$ & $3080.41 \pm 24.02^{\mathrm{t}}$ & $73.87 \pm 3.12^{\mathrm{no}}$ \\
\hline V. myrtillus(2012) & $1.48 \pm 0.07^{\mathrm{b}}$ & $2830.73 \pm 11.52^{\mathrm{s}}$ & $76.71 \pm 1.18^{\circ}$ \\
\hline V. myrtillus (2013) & $1.01 \pm 0.02^{\mathrm{a}}$ & $3632.96 \pm 82.25^{u}$ & $86.48 \pm 0.77^{\mathrm{P}}$ \\
\hline
\end{tabular}

Different letters ( $\mathrm{a}-\mathrm{z})$ in the same columns are significantly different at the $5 \%$ level $(\mathrm{p}<0.05)$. Std. Troloks ${ }^{*} 0,008 \pm 0,0001 ; \mathrm{BHT} \% 100$

different study the antioxidant capacities of the hybrids 'Northblue', 'Northsky', 'Northcoutry' of $V$. angustifolium $\times$ corymbosum (VAAC) and the hybrids 'Bluerop', 'Bluejay' and 'Jersey' of the variety $V$. corymbosum (VACM) were examined using the ORAC and FRAP methods. The results showed that the ORAC and FRAP values for 'Northblue' were 26.0 and $26.1 \mu \mathrm{mol}$ troloks/g, 34.2 and $39.9 \mu \mathrm{mol}$ troloks/g for 'Northcountry', and 31.3 and 30.5 $\mu \mathrm{mol}$ troloks/g for 'Northsky'. On the other hand, it is noted that the ORAC and FRAP values for 'Bluecrop' were 22.1 and $20.2 \mu \mathrm{mol}$ troloks $/ \mathrm{g}, 20.7$ and $25.5 \mu \mathrm{mol}$ troloks $/ \mathrm{g}$ for 'Bluejay', 21.5 and $18.9 \mu \mathrm{mol}$ troloks/g for 'Jersey'. In the same study, the antioxidant capacities of the hybrids $V$. deliciosum (VADE), $V$. membranaceum (VAME), $V$. ovalifolium (VAOF), $V$. ovatum (VAOV), $V$. oxycoccus (VAOX), $V$. parvifolium (VAPA) and $V$. ulignosum
(VAUG) were examined. The mean ORAC and FRAP values of the hybrids were determined as follows: 30.5 and $32.2 \mu \mathrm{mol}$ troloks/g for VAAC, 21.4 and $21.5 \mu \mathrm{mol}$ troloks/g for VACM, 14.6 and $30.2 \mu \mathrm{mol}$ troloks/g for VADE, 21.0 and $40.5 \mu \mathrm{mol}$ troloks/g for VAME, 37.8 and $76.2 \mu \mathrm{mol}$ troloks/g for VAOF, 41.1 and $70.2 \mu \mathrm{mol}$ troloks/g for VAOV, 13.5 and $25.8 \mu \mathrm{mol}$ troloks/g for VAOX, 7.3 and $10.0 \mu \mathrm{mol}$ troloks/g for VAPA and 29.3 and $26.1 \mu \mathrm{mol}$ troloks/g for VAUG (Taruscio et al., 2004). In this study, the FRAP values of 'Northcountry' and 'Bluecrop' were lower, 'Bluejay' and 'Jersey' were similar findings compared with literature (Taruscio et al., 2004). The mean FRAP value was $14.44 \mu \mathrm{mol}$ troloks/g and this value was found to be lower than that of all other varieties except VAPA with literature study (Taruscio et al., 2004). It was reported in the results of another study, where the antioxidant capacities of the high northern and southern 
hybrid blueberries were examined by the ORAC method that the antioxidant capacity was in a range between 4.6 and $31.11 \mu \mathrm{mol}$ troloks $/ \mathrm{g}$. It was found that the antioxidant capacities of 'Berkeley' (5.5 $\mu \mathrm{mol}$ troloks/g), 'Darrow' (14.8 umol troloks/g), 'Duke' (16.1 umol troloks/g), 'Spartan' (14.11 umol troloks/g) and 'Sunshine' (11.7 umol troloks $/ \mathrm{g})$ were lower. The antioxidant capacity of the remaining 'Bluecrop' (10.4 $\mu \mathrm{mol}$ troloks $/ \mathrm{g})$, 'Bluegold' (14.9 umol troloks/g), 'Brigitta' (17.7 umol troloks/g), 'Chandler' (17.8 $\mu \mathrm{mol}$ troloks/g), 'Herbert' (19.7 $\mu \mathrm{mol}$ troloks/g), 'Jersey' (19.3 umol troloks/g), 'Jubile' (15.5 $\mu \mathrm{mol}$ troloks/g), 'Oneil' (14.1 umol troloks/g), 'Legasi' (13.5 $\mu \mathrm{mol}$ troloks/g),

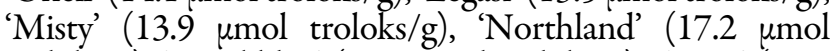
troloks/g), 'Ozarkblue' (17.0 umol troloks/g), 'Puru' (22.1 $\mu \mathrm{mol}$ troloks/g) and 'Torro' (19.8 $\mu \mathrm{mol}$ troloks/g) were found to be higher than those in this study. However, these differences are not significant with the exception of 'Toro', 'Bluejay', 'Chandler', 'Earliblue', 'Oneil' and 'Puru' (Ehlenfeldt and Prior, 2001). A study conducted in Italy analyzed the antioxidant capacities of $V$. myrtillus blueberries using the FRAP method and found that the antioxidant capacities were higher in $V$. myrtillus than those of hybrid berries ('Goldtrauble', 'Patriot', 'Bluecrop', 'Darrow'). In this aspect, it shows a similarity with this study. However, the antioxidant capacity of the hybrid and natural berries was found to be much higher than in this study. This is due to the fact that the berry contents and types vary depending on the climate, irrigation, altitude and geographical conditions (Akerström et al., 2010; Ribera et al., 2010; Ehret, 2012).

\section{Phenolic compounds of blueberry fruits}

Phenolics are large group of compounds found many in plants. These compounds inhibit free radicals, which are generated as a waste of the cell metabolism in the human body, and prevent DNA deformation. In particular, phenolic acids like chlorogenic acid and vanillin are major the compounds among the phenolic compounds with the highest radicals scavenge effect (Sawa et al., 1999). Blueberries compounds were analysed with HPLC-DAD and these findings are illustrated in Table 4 . The analysis was conducted with seventeen standard phenolic compounds and chlorogenic acid was found to be the dominant compound among all of the berries. The compounds gallic acid, protochatecuic acid, $\mathrm{p}-\mathrm{OH}$ benzoic acid, vanillic acid, ellagic acid, rosmarinic acid, o-coumaric acid and curcumin were not found in any of the berries. Compounds such as caffeic acid, syringic acid, $t$-cinnamic acid, ferulic acid and benzoic acid were found at different levels in some berries. The amount of chlorogenic acid found in the natural berries was higher than the one of the cultivars. The amount of phenolic compounds in the natural berries was much higher than in the cultivar varieties. In addition to this, when the berries of the same variety were obtained from different regions, there were significant differences between the amounts of phenolic compounds found in 'Bluecrop' obtained from Kaşüstü and Bulancak, 'Bluegold' obtained from Rize and Bulancak, 'Bluejay' obtained from Bulancak and Kaşüstü. However, the difference in the amount of phenolic compounds found in the 'Brigitta' samples collected from the Bulancak and Hayrat regions and Toro samples from the Hayrat and
Kaşüstü regions is quite high. When the $V$. arctostaplylos and $V$. myrtillus samples obtained in 2012 and 2013 were examined, similar compounds were revealed for both varieties. While quercetin was not found in 2012 in V. arctostaplylos, this compound was found in 2013. Similarly, while p-coumaric acid was not found in 2012 in $V$. myrtillus, it was found in 2013. Otherwise, the amounts of phenolic compounds found in both years are different. For example, while the amount of chlorogenic acid found in $V$. arctostaplylos in 2012 was $45.6 \mathrm{mg} / 100 \mathrm{~g}$, in 2013 it decreased to $17.66 \mathrm{mg} / 100 \mathrm{~g}$.

Zimmer et al. (2014), reported as a result of the qualitative analysis they performed on hybrid blueberries ('Briteblue', 'Bluegem' and 'Woodard') that chlorogenic acid is the most dominant compound. Authors also found low amounts of quercetin and caffeic acid except in these two compounds (Zimmer et al., 2014). The literature is largely in parallel with this study and quercetin is found in the existing study only in some fruit varieties.

Another study conducted in China examined the HPLC and the phenolic compounds of Lanfeng blueberries. The researchers determined that ferulic acid was the most dominant compound among the phenols in berries with $1.280 \mathrm{~g} \mathrm{~kg}^{-1}$ (dry weight). Furthermore, caffeic acid was determined to be the second most dominant compound with $1.217 \mathrm{~g} \mathrm{~kg}^{-1}$ (dry weight). Additionally, the study examined $p$-coumaric acid $\left(1.154 \mathrm{~g} \mathrm{~kg}^{-1}\right.$ (dry weight), syringic acid $\left(0.997 \mathrm{~g} \mathrm{~kg}^{-1}\right.$ (dry weight), vanillic acid $(0.170 \mathrm{~g}$ $\mathrm{kg}^{-1}$ (dry weight) and gallic acid $\left(0.142 \mathrm{~g} \mathrm{~kg}^{-1}\right.$ (dry weight). However, the study did not determine the dry weight of quercetin and kaempferol (Yang et al., 2014). Compared with this study, gallic acid and vanillic acid were not found in any blueberry variety. Ferulic acid was determined in 'Bluecrop', 'Blueray', 'Brigitta', 'Darrow', 'Misty', 'Oneil', 'Sunshine' and 'V.myrtillus' caffeic acid and syringic acid were found in most of the blueberry varieties. However, quercetin was determined in a small amounts of blueberries. According to Häkkinen (2000), the reason for this is that the hybrids of the same plant variety demonstrate differences in the synthesis of the phenolic compounds (Häkkinen, 2000). In a study conducted on the 'Duke' hybrid of $V$. corymbosum, HPLC-DAD analysis on plant varieties demonstrated that the largest phenolic compound was chlorogenic acid. The amount of chlorogenic acid in 'Duke' was determined as $25.42 \mathrm{mg} / 100 \mathrm{~g}, 1.59 \mathrm{mg} / 100 \mathrm{~g}$ quercetin, and $1.02 \mathrm{mg} / 100 \mathrm{~g}$ kaempferol (Zheng et al., 2003). Similar results were found in this study and it was seen that the most dominant compound was chlorogenic acid. However, quercetin was not found. Previous studies conducted on blueberries illustrated that quercetin was much more prevalent than myricetin and kaempferol. Moreover, ferulic acid was found to be the main compound in blueberries (Stör and Hermann, 1975). Similar results were found in a study conducted by Häkkinen (2000). They also reported in this study that there was no ferulic acid in any of the blueberries. Researcher explained that this was because the peaks of unknown hydroxycinnamate compounds could not be observed due to the dilution of the ferulic acid in the blueberry samples. As a result of this, the peak of ferulic acid disappeared. In addition, the determined that the amount of caffeic acid in 'Northcountry' was very 
648

Table 4. The phenolic compound results of blueberry fruits with HPLC-DAD (mean \pm SD measured as $\mathrm{mg} / 100 \mathrm{~g}$ sample)

\begin{tabular}{|c|c|c|c|c|c|c|c|c|}
\hline Cultivar & $\begin{array}{c}\text { Chlorogenic } \\
\text { Acid }\end{array}$ & Caffeic Acid & Syringic Acid & Ferulic Acid & Rutin & Benzoic Acid & Quercetin & $p$-Coumaric Acid \\
\hline $\begin{array}{l}\text { Berkeley } \\
\text { (Kaşüstü) }\end{array}$ & $2.16 \pm 0.27$ & N.D. & N.D. & N.D. & $0.39 \pm 0.08$ & N.D. & N.D. & N.D. \\
\hline $\begin{array}{l}\text { Bluecrop } \\
\text { (Bulancak) }\end{array}$ & $2.87 \pm 0.07$ & $0.03 \pm 0.01$ & N.D. & N.D. & $0.71 \pm 0.04$ & N.D. & N.D. & N.D. \\
\hline $\begin{array}{l}\text { Bluecrop } \\
\text { (Rize) }\end{array}$ & $2.36 \pm 1.42$ & $0.07 \pm 0.02$ & N.D. & $0.01 \pm 0.02$ & $0.59 \pm 0.09$ & N.D. & N.D. & N.D. \\
\hline $\begin{array}{c}\text { Bluegold } \\
\text { (Bulancak) }\end{array}$ & $3.49 \pm 0.76$ & $0.37 \pm 0.01$ & $0.10 \pm 0.04$ & N.D. & $0.53 \pm 0.03$ & N.D. & N.D. & N.D. \\
\hline $\begin{array}{l}\text { Bluegold } \\
\text { (Hayrat) }\end{array}$ & $4.15 \pm 0.3$ & $0.20 \pm 0.05$ & $0.13 \pm 0.01$ & N.D. & $0.59 \pm 0.14$ & N.D. & N.D. & N.D. \\
\hline $\begin{array}{c}\text { Bluejay } \\
\text { (Bulancak) }\end{array}$ & $0.97 \pm 0.02$ & N.D. & $0.21 \pm 0.03$ & N.D. & $0.22 \pm 0.03$ & N.D. & N.D. & N.D. \\
\hline $\begin{array}{c}\text { Bluejay } \\
\text { (Kaşüstü) }\end{array}$ & $1.31 \pm 0.1$ & N.D. & $0.26 \pm 0.05$ & N.D. & $0.51 \pm 0.06$ & N.D. & N.D. & N.D. \\
\hline $\begin{array}{l}\text { Blueray } \\
\text { (Kaşüstü) }\end{array}$ & $4.82 \pm 0.07$ & $0.002 \pm 0.06$ & $0.009 \pm 0.05$ & $0.0031 \pm 0.01$ & $0.60 \pm 0.2$ & N.D. & N.D. & N.D. \\
\hline $\begin{array}{c}\text { Brigitta } \\
\text { (Bulancak) }\end{array}$ & $2.13 \pm 0.2$ & N.D. & $0.29 \pm 0.09$ & N.D. & $1.27 \pm 0.1$ & N.D. & N.D. & N.D. \\
\hline $\begin{array}{l}\text { Brigitta } \\
\text { (Hayrat) }\end{array}$ & $8.26 \pm 1.19$ & N.D. & $0.67 \pm 0.12$ & $0.0025 \pm 0.003$ & $0.93 \pm 0.08$ & N.D. & N.D. & N.D. \\
\hline $\begin{array}{l}\text { Chandler } \\
\text { (Bulancak) }\end{array}$ & $3.97 \pm 0.02$ & N.D. & N.D. & N.D. & $0.0046 \pm 0.05$ & N.D. & N.D. & N.D. \\
\hline $\begin{array}{c}\text { Darrow } \\
\text { (Bulancak) }\end{array}$ & $3.05 \pm 0.22$ & N.D. & N.D. & $0.0150 \pm 0.021$ & $0.69 \pm 0.01$ & N.D. & N.D. & N.D. \\
\hline Duke (Kaşüstü) & $7.58 \pm 0.03$ & N.D. & N.D. & N.D. & $0.65 \pm 0.30$ & N.D. & N.D. & N.D. \\
\hline $\begin{array}{c}\text { Early Blue } \\
\text { (Rize) }\end{array}$ & $2.54 \pm 0.62$ & N.D. & $\mathbf{0 . 3 0} \pm \mathbf{0 . 0 7}$ & N.D. & $1.11 \pm 0.13$ & N.D. & $0.44 \pm 0.07$ & N.D. \\
\hline $\begin{array}{l}\text { Herbert } \\
\text { (Kaşüstü) }\end{array}$ & $3.65 \pm 0.95$ & $3.16 \pm 0.4$ & N.D. & N.D. & $0.72 \pm 0.04$ & N.D. & N.D. & N.D. \\
\hline Jersey (Hayrat) & $2.97 \pm 0.07$ & N.D. & N.D. & N.D. & $0.58 \pm 0.09$ & N.D. & N.D. & N.D. \\
\hline $\begin{array}{c}\text { Jubile } \\
\text { (Bulancak) }\end{array}$ & $4.01 \pm 0.05$ & $0.92 \pm 0.04$ & N.D. & N.D. & N.D. & $0.44 \pm 0.06$ & N.D. & N.D. \\
\hline $\begin{array}{c}\text { Legasi } \\
\text { (Kaşüstü) }\end{array}$ & $10.68 \pm 0.66$ & $0.0091 \pm 0.002$ & N.D. & N.D. & $0.31 \pm 0.05$ & N.D. & N.D. & N.D. \\
\hline $\begin{array}{c}\text { Misty } \\
\text { (Bulancak) }\end{array}$ & $4.07 \pm 0.12$ & $0.0061 \pm 0.008$ & $0.0033 \pm 0.04$ & $0.0045 \pm 0.02$ & $1.52 \pm 0.04$ & N.D. & N.D. & N.D. \\
\hline $\begin{array}{l}\text { Northcountry } \\
\text { (Kaşüstü) }\end{array}$ & $2.76 \pm 0.11$ & $0.069 \pm 0.09$ & N.D. & N.D. & $0.56 \pm 0.13$ & N.D. & N.D. & N.D. \\
\hline $\begin{array}{l}\text { Northland } \\
\text { (Bulancak) }\end{array}$ & $0.50 \pm 0.05$ & N.D. & $0.46 \pm 0.12$ & N.D. & $0.54 \pm 0.05$ & N.D. & N.D. & N.D. \\
\hline $\begin{array}{c}\text { Oneil } \\
\text { (Bulancak) }\end{array}$ & $2.49 \pm 0.17$ & N.D. & $0.67 \pm 0.33$ & $0.0031 \pm 0.002$ & $1.32 \pm 0.01$ & N.D. & N.D. & N.D. \\
\hline $\begin{array}{c}\text { Patriot } \\
\text { (Kaşüstü) }\end{array}$ & $4.9 \pm 3.22$ & N.D. & N.D. & N.D. & $0.63 \pm 0.3$ & N.D. & N.D. & N.D. \\
\hline Puru (Kaşüstü) & $10.36 \pm 4.1$ & N.D. & N.D. & N.D. & $1.11 \pm 1.23$ & N.D. & N.D. & N.D. \\
\hline Putte Sampling & $2.69 \pm 0.76$ & N.D. & N.D. & N.D. & $2.73 \pm 1.64$ & N.D. & N.D. & N.D. \\
\hline $\begin{array}{l}\text { Spartan } \\
\text { (Kaşüstü) }\end{array}$ & $2.95 \pm 1.5$ & N.D. & N.D. & N.D. & $0.27 \pm 0.1$ & N.D. & N.D. & N.D. \\
\hline $\begin{array}{c}\text { Sunrise } \\
\text { (Bulancak) }\end{array}$ & $9.94 \pm 1.83$ & $1.23 \pm 0.02$ & N.D. & N.D. & $0.86 \pm 0.15$ & N.D. & N.D. & N.D. \\
\hline $\begin{array}{l}\text { Sunshine } \\
\text { (Bulancak) }\end{array}$ & $8.83 \pm 0.25$ & $1.95 \pm 0.14$ & N.D. & $0.046 \pm 0.04$ & $0.71 \pm 0.36$ & N.D. & N.D. & N.D. \\
\hline $\begin{array}{c}\text { Toro } \\
\text { (Hayrat) }\end{array}$ & $1.79 \pm 0.11$ & N.D. & N.D. & N.D. & $0.11 \pm 0.01$ & N.D. & N.D. & N.D. \\
\hline $\begin{array}{c}\text { Toro } \\
\text { (Kaşüstü) }\end{array}$ & $0.6 \pm 0.02$ & N.D. & $0.11 \pm 0.08$ & N.D. & $0.20 \pm 0.7$ & N.D & $0.02 \pm 0.01$ & N.D \\
\hline $\begin{array}{l}\text { V. arctostaplylos } \\
(2012)\end{array}$ & $45.6 \pm 7.79$ & $0.84 \pm 0.1$ & N.D. & N.D. & N.D. & N.D. & N.D. & $0.0051 \pm 0.003$ \\
\hline $\begin{array}{l}\text { V. arctostaplylos } \\
\text { (2013) }\end{array}$ & $17.66 \pm 2.77$ & $0.28 \pm 0.07$ & N.D. & N.D. & N.D. & N.D. & $0.07 \pm 0.02$ & $0.61 \pm 0.28$ \\
\hline $\begin{array}{c}\text { V. myrtillus } \\
\text { (2012) }\end{array}$ & $15.74 \pm 0.33$ & $1.96 \pm 0.22$ & N.D. & $0.20 \pm 0.08$ & N.D. & N.D. & N.D. & N.D. \\
\hline $\begin{array}{c}\text { V. myrtillus } \\
\text { (2013) }\end{array}$ & $30.13 \pm 8.47$ & $0.4 \pm 0.21$ & N.D. & N.D. & N.D. & N.D. & N.D. & $0.55 \pm 0.08$ \\
\hline
\end{tabular}

Gallic acid, protocatechuic acid,p-OH benzoic Acid, Vanilic Asid, Ellagic Asit, Benzoic Asid, Rosmarinic Asid,o-Coumaric Asid,t-Cinnamic Asid,Curcumin couldn't be determined. 
low and, along with this, that the main phenolic compound of the fruits of $V$. myrtillus was $p$-coumaric acid (Häkkinen, 2000). A similar situation is valid for this study, too, and much less amounts of caffeic acid were found in the 'Northcountry' hybrid. The dominant compound after chlorogenic acid in $V$. myrtillus berries was p-coumaric acid. It was reported by Ribera et al. (2010) conducted on blueberries that chlorogenic acid and rutin were the dominant compounds in fruits. In addition, compounds such as gallic acid, caffeic acid and ferulic acid were found. The amounts of these compounds were found to be quite low compared with chlorogenic acid and rutin (Ribera et al., 2010). Zheng and Wang (2003), reported in the results of their study conducted on the Vaccinium corymbosum hybrid that chlorogenic acid was the most dominant phenolic acid with $64.59 \mathrm{mg} / 100 \mathrm{~g}$. However, in contradiction to the literature, no vanillic acid, caffeic acid and derivates, $p$ coumaric acid and kaempferol were determined (Zheng and Wang, 2003). There is a similar situation with Zheng and Wang (2003) compared with this study and it was determined that the amount of chlorogenic acid was quite low.

\section{Determination of the sugar amounts of blueberry fruits}

Sugar compounds are an important psychological process used for determining the quality of sweet fruits. Among these compounds, fructose is especially significant (Kafkas et al., 2008). Sugar compounds and amounts are indicated in Table 5. According to this, fructose and glucose sugar were determined as the major monosaccharide in blueberries. In addition to these sugar compounds, sucrose was also found in a large majority of blueberries. Except these, no other sugars were found in any berry variety. While the highest fructose ratio among the berries was identified in 'Patriot', the highest glucose ratio was found in 'Darrow' and 'Duke'. The highest sucrose ratio was found in 'Toro'. The results reveal that the sugar ratios in the others berries varieties were close to each other.

Glycose, fructose, sucrose and malt-sugar were found in the fruit juices as a result of the study conducted on the sugar compounds of blueberry fruit juices made of $V$. corymbosum hybrids. The findings report $3.1 \mathrm{mg} / 100 \mathrm{~g}$ glucose, $4.1 \mathrm{mg} / 100 \mathrm{~g}$ fructose, $0.4 \mathrm{mg} / 100 \mathrm{~g}$ sucrose and 0.5 $\mathrm{mg} / 100 \mathrm{~g}$ malt-sugar. Beside this, the authors have stated that the amounts of fructose and glucose were close to each other (Nindo et al., 2005). Fructose, glucose and sucrose compounds were found in the fully ripened fruits as a result of the sugar analysis of $V$. arctostaphylos and $V$. myrtillus collected in the Black Sea Region. It was reported that the compounds found in $V$. arctostaphylos were $25.32 \%$ fructose, $26.20 \%$ glucose and $1.02 \%$ sucrose. These ratios are reported for $V$. myrtillus as $32.90 \%$ fructose and glucose and $1.81 \%$ sucrose. Briefly, the amounts of the sugar compounds found in $V$. arctostaphylos were lower than those in $V$. myrtillus. Furthermore, the fructose and glucose ratios determined in these berries were very close (Ayaz et al., 2001). In another study conducted by Hirvi and Honkanen (1983), on Vaccinium corymbosum hybrids and Vaccinium uliginosum, fructose and glucose were found in all berries. The fructose amount of the hybrid berries varied between $29-71 \mathrm{~g} / \mathrm{kg}$, while the glucose amounts varied between $27-69 \mathrm{~g} / \mathrm{kg}$ (Hirvi and Honkanen, 1983).

Table 5. Sugar analysis results of the blueberry fruits (mean \pm SD measured as $\mathrm{mg} / 100 \mathrm{~g}$ sample)

\begin{tabular}{|c|c|c|c|}
\hline Sample & Fructose & Glucose & Sucrose \\
\hline Berkeley (Kaşüstü) & $6.06 \pm 0.05$ & $6.61 \pm 0.11$ & $2.93 \pm 0.11$ \\
\hline Bluecrop (Bulancak) & $10.55 \pm 0.25$ & $10.24 \pm 0.20$ & $3.11 \pm 0.10$ \\
\hline Bluegold (Bulancak) & $8.34 \pm 0.08$ & $8.76 \pm 0.28$ & N.D. \\
\hline Bluejay (Bulancak & $9.84 \pm 0.17$ & $10.33 \pm 0.08$ & $3.51 \pm 0.06$ \\
\hline Blueray (Kaşüstü) & $8.10 \pm 0.06$ & $7.98 \pm 0.36$ & $2.70 \pm 0.04$ \\
\hline Brigitta (Bulancak) & $9.44 \pm 0.07$ & $11.92 \pm 0.10$ & N.D. \\
\hline Chandler (Bulancak) & $12.14 \pm 0.18$ & $10.96 \pm 0.14$ & $3.01 \pm 0.02$ \\
\hline Darrow (Bulancak) & $12.07 \pm 0.18$ & $12.85 \pm 0.37$ & $2.90 \pm 0.40$ \\
\hline Duke (Kaşüstü) & $11.73 \pm 0.13$ & $12.03 \pm 0.35$ & $3.40 \pm 0.04$ \\
\hline Early Blue (Rize) & $7.82 \pm 0.55$ & $7.58 \pm 0.31$ & N.D. \\
\hline Herbert (Kaşüstü) & $10.55 \pm 0.25$ & $10.24 \pm 0.20$ & $3.11 \pm 0.10$ \\
\hline Jersey (Hayrat) & $11.15 \pm 0.12$ & $10.91 \pm 0.24$ & $3.07 \pm 0.16$ \\
\hline Jubile (Bulancak) & $9.12 \pm 0.37$ & $8.90 \pm 0.28$ & $2.80 \pm 0.05$ \\
\hline Legasi (Kaşüstü) & $7.97 \pm 0.15$ & $8.45 \pm 0.24$ & $2.90 \pm 0.11$ \\
\hline Misty (Bulancak) & $9.56 \pm 0.31$ & $8.16 \pm 0.36$ & $2.60 \pm 0.14$ \\
\hline Northcountry (Kaşüstü) & $9.11 \pm 0.12$ & $9.06 \pm 0.12$ & $1.23 \pm 0.05$ \\
\hline Northblue (Bulancak) & $4.99 \pm 0.06$ & $6.07 \pm 0.03$ & $2.92 \pm 0.04$ \\
\hline Northland (Bulancak) & $12.11 \pm 0.17$ & $10.35 \pm 0.04$ & $2.61 \pm 0.04$ \\
\hline Oneil (Bulancak) & $9.42 \pm 0.03$ & $8.33 \pm 0.04$ & $2.62 \pm 0.20$ \\
\hline Ozarkblue (Bulancak) & $6.28 \pm 0.12$ & $7.13 \pm 0.14$ & $2.74 \pm 0.06$ \\
\hline Patriot (Kaşüstü) & $13.74 \pm 0.05$ & $11.14 \pm 0.03$ & $1.20 \pm 0.06$ \\
\hline Puru (Kaşüstü) & $11.83 \pm 0.12$ & $11.05 \pm 0.10$ & $3.33 \pm 0.11$ \\
\hline Putte Sampling (Kaşüstü) & $7.54 \pm 0.44$ & $8.32 \pm 0.17$ & $2.81 \pm 0.20$ \\
\hline Spartan (Kaşüstü) & $8.75 \pm 0.13$ & $9.18 \pm 0.05$ & $3.82 \pm 0.40$ \\
\hline Sunrise (Bulancak) & $9.63 \pm 0.35$ & $8.63 \pm 0.04$ & N.D. \\
\hline Sunshine (Bulancak) & $4.73 \pm 0.02$ & $4.44 \pm 0.08$ & N.D. \\
\hline Toro (Hayrat) & $10.83 \pm 0.10$ & $10.96 \pm 0.51$ & $3.51 \pm 0.30$ \\
\hline$V$. arctostaplylos & $5.96 \pm 0.15$ & $5.17 \pm 0.06$ & N.D. \\
\hline V. myrtillus & $7.95 \pm 0.22$ & $8.05 \pm 0.09$ & N.D. \\
\hline
\end{tabular}


Table 6. Correlation results of the analysis performed at blueberry fruits

\begin{tabular}{ccccccc}
\hline & TPC & TFC & TAC & DPPH & FRAP & $\beta$-Carotene \\
\hline TPC & $\mathbf{1}$ & 0.464 & 0.588 & 0.713 & 0.765 & 0.709 \\
TFC & 0.464 & $\mathbf{1}$ & 0.826 & 0.546 & 0.556 & 0.499 \\
TAC & 0.588 & 0.826 & $\mathbf{1}$ & 0.676 & 0.729 & 0.526 \\
DPPH & 0.713 & 0.546 & 0.676 & $\mathbf{1}$ & 0.932 & 0.627 \\
FRAP & 0.765 & 0.556 & 0.729 & 0.932 & $\mathbf{1}$ & 0.613 \\
$\beta$-Carotene & 0.709 & 0.499 & 0.526 & 0.627 & 0.613 & $\mathbf{1}$ \\
\hline Correlation at 0.01 level is important. & & & & &
\end{tabular}

\section{Correlation analysis for blueberries}

This study used the Pearson Correlation Tests to determine the relation of total polyphenol, flavonoid, anthocyanin, DPPH, FRAP and $\beta$-Carotene analysis in the blueberries. The results are shown in Table 6.

While a medium correlation was determined between polyphenol and flavonoid, there was a high correlation between polyphenol and anthocyanin. Also, there was a high correlation between FRAP, one of the antioxidant methods, $\beta$-carotene and DPPH and polyphenol. Among these was a highly correlation between DPPH and polyphenol. While there was a slight correlation between FRAP values and $\beta$-carotene, a slightly correlation was determined between DPPH and flavonoid. There was a strong positive correlation between flavonoid and anthocyanin. The Pearson Correlation revealed that there was a high positive correlation between anthocyanin and FRAP, a medium correlation between anthocyanin and $\beta$ carotene, a medium correlation between anthocyanin and DPPH. A highly correlation was found between DPPH, FRAP and $\beta$-carotene.

Many of the studies conducted on food have shown that the total polyphenol and total anthocyanin amounts have an important effect on antioxidant capacity. This has been proven in the majority of studies by the high correlation between the total amount of polyphenols and the total amount of anthocyanin (Uzelac et al., 2009). At the result of the study, where the correlation between the antioxidant (ORAC), total phenol and anthocyanin results of the blueberry fruits is examined, there is a low but meaningful correlation between the phenolic amount and the anthocyanin amount determined in blueberries (Ehlenfeldt and Prior, 2001). Connor et al. (2002) found a high correlation between the antioxidant activity and the total polyphenol compounds $(r=0,88)$. Besides, they also found a low correlation between anthocyanin and antioxidants $(\mathrm{r}=0,61)$ (Connor et al., 2002). Additionally, there was no correlation between the phenolic compounds and antioxidants and total phenolic amounts $(\mathrm{r}=0,30)$. However, there was a strong correlation between the flavonol amounts and the antioxidant activity $(\mathrm{r}=0,78)$ (Kahkönen et al., 2001). The total polyphenol, total flavonoid and total antioxidant amounts of different blueberry hybrids were examined by 4 different antioxidant methods (FRAP, ABTS, ORAC and DPPH). It was reported that there was a high correlation between the antioxidant methods (Bunea et al., 2011).

\section{Conclusions}

Our findings reveal that the total polyphenol, total anthocyanin, total flavonoid and antioxidant contents of natural blueberries were higher compared with those of the cultivars. Furthermore, blueberries are a high antioxidant source. As a result of the HPLC-DAD analysis conducted on blueberries, our findings demonstrate that the dominant compound was chlorogenic acid. Fructose and glucose were found in all berries as result of the sugar analysis. In addition to this, sucrose was found in a great majority of the berries. However, the amount of sucrose was lower than fructose and glucose. There were quite significant differences observed with regards to phenolic and antioxidant attributes between the samples of the same berry variety collected from different regions and the same berry variety collected from the same regions during different years. It is thought that the reason for this is the genotype and climatic differences between the hybrids. While a medium correlation was found between the total polyphenol, total flavonoid, total anthocyanin contents, there was a strong correlation between the antioxidant results of the different methods (FRAP, DPPH, $\beta$-Carotene).

The data shows cultivars are also comparable with naturally grown species (low bush blue berry native to Turkey) regarding bioactivity as well as composition. According to findings the northern highbush species are the most suitable species for the Black Sea region.

\section{Acknowledgements}

This project is supported by the SAN-TEZ program of the Ministry for Science, Industry and Technology within the scope of the project with the code number 928 STZ.2011/1.

\section{References}

Akerström A, Jaakola L, Bang U, Jaderlund A (2010). Effect of latituderelated factors and geographical origin on anthocyanidin concentration in fruits of Vaccinium myrtillus L. (bilberries). Journal of Agriculture and FoodChemistry 58(23):11939-11945.

Ayaz FA, Kadıoğlu A, Bertoft C, Acar C, Turna I (2001). Effect of fruit maturation on sugar and organic acid composition in two blueberries (V. antostaphylos and $V$. myrtillus) native to Turkey. New Zealand Journal of Crop and Horticultural Science 29:137-141.

Benzie IFF, Strain JJ (1999). Ferric reducing/antioxidant power assay: direct measure of total antioxidant activity of biological fluids and modified version for simultaneous measurement of total antioxidant power and ascorbic acid concentration. Methods in Enzymology 299:15-27.

Brambilla A, Scalzo RL, Bertolo G, Torreggiani D (2008). Steam-blanched highbush blueberry (Vacinium corymbosum L.) juice: phenolic profile and antioxidant capacity in relation to cultivar selection. Journal of Agricultural and Food Chemistry 56(8):2643-2648. 
Bunea A, Rugina DO, Pintea AM, Sconta Z, Bunea CI, Socaciu C (2011). Comparative polyphenolic content and antioxidant activities of some wild and cultivated blueberries from Romania. Notulae Botanicae Horti AgrobotaniciCluj-Napoca39(2):70-76.

Can Z, Yildiz O, Sahin H, Turumtay EA, Silici S, Kolaylı S (2015). An investigation of Turkish honeys: Their physico-chemical properties, antioxidant capacities and phenolic profiles. Food Chemistry 180:133141.

Celik H (2009). The performance of some northen highbush blueberry (Vacinium corymbosum L.) varieties in north eastern part of Anatolia. Anadolu Journal of Agriculture Science 24(3):141-146.

Connor AM,Luby JJ, Tong CBS, Finn CE, HancockJF (2002). Genotypic and environmental variation in antioxidant activity, total phenolic content and anthociyanin content among blueberry cultivars. Journal of the American Society for Horticultural Science 127(1):89-97.

Ehlenfeldt MK, Prior RL (2001). Oxygen radical absorbance capacity (ORAC) and phenolic and anthocyanin concentrations in fruit and leaf tissues of highbush blueberry. Journal of Agricultural and Food Chemistry 49:2222-2227.

Ehret DL, Frey B, Forge T, Helmer T (2012). Effect of drip irrigation configuration and rate on yield and fruit quality of young highbush blueberry plants. HortScience 47(3):414421.

Ercisli S, Celik H (2009). Mulberry and blueberry cultivation in Turkey. Pomologia Croatica 14(4):281-288.

Gao G, Draper E (2010). Growing blueberries in the home garden. Agriculture and Natural Resources 1-8.

Giovanelli G, Buratti S (2009). Comparison of polyphenolic composition and antioxidant activity of wild Italian blueberries and some cultivated varieties. Food Chemistry 112:903-908.

Giusti MM, Wrolstad RE (2001). Anthocyanins characterization and measurement with UV-visible spectroscopy. In: Wrolstad R, Acree TE, AnH,DeckerEA, Penner MH, ReidDS, SchwartzSJ, Shoemaker CF, Sporns P (Eds). Current Protocols in Food Analytical Chemistry, Unit F1.2. New York, John Wiley \& Sons, Inc pp 1-13.

Häkkinen SH, Törrönen RA (2000). Content of flavonols and selected phenolic acids in strawberries and Vaccinium species: Influence of cultivar, cultivation site and technique. Food Research International 33:517-524.

Hatipoğlu G, Sökmen M, BektaşE, Daferera D, Sökmen A, Demir E, Şahin $\mathrm{H}$ (2013). Automated and standard extraction of antioxidant phenolic compounds of Hyssopus officinalis L. ssp. angustifolius. Industrial Crops and Products 43:427-433.

Hirvi T, Honkanen E (1983). The aroma of some hybrids between Highbush Blueberry (Vaccinium corymbosum, L.) and Bog Blueberry (Vacinium uliginosum, L.).Zeitschrift fur Lebensmittel-Untersuchung und-Forschung 176:346-349.

Huang D, Ou B, Prior RL (2005). The chemistry behind antioxidant capacity assays. Journal of Agricultural and Food Chemistry 53:43034310.

Kafkas E, Koşar M, Türemiş N, Başer KHC (2006). Analysis of sugars, organic acids and vitamin $\mathrm{C}$ contents of blackberry genotypes from Turkey. Food Chemistry 97:732-736.

KafkasE, Özgen M, Özoğul Y, Türemiş N (2008). Phytochemical and fatty acid profile of selected red raspberry cultivars: A comparative study. Journal of Food Quality 31:67-78.

Kahkönen PM, Hopia AI, Heinonen M (2001). Berry phenolics and their antioxidant activity. Journal of Agricultural and Food Chemistry 49:4076-4082.

Kalt W, Dufour D (1997). Health functionality of blueberries. Journal of Horthtechnology 7(3):216-221.

Kalt W, Mcdonald JE, Donner H (2000). Anthocyanins, phenolics and antioxidant capacity of processed lowbush blueberry products. Journal of Agricultural and Food Chemistry 65:390-393.

Kalt W, Ryan DAJ, Duy JC, Prior RL, Ehlenfeldt MK, Kloet SPV (2001). Interspecific variation in anthocyanins, phenolics and antioxidant capacity among genotypes of highbush and lowbush blueberries (Vaccinium section cyanococcus spp.). Journal of Agricultural and Food Chemistry 49:4761-4767.

Kartal N, Sökmen M,Tepe B, Daferera D, Polissiou M, Sökmen A (2007). Investigation of the antioxidant properties of Ferula orientalis L. using a suitable extraction procedure. Food Chemistry 100:584589.

Koca I, Karadeniz B (2009). Antioxidant properties of blackberry and blueberry fruits grown in the Black Sea Region of Turkey. Scientia Horticulturae 121:447-450.

Lamaison JL, Carnat A (1991). Teneurs en principaux flavonoïdes des fleurs et des feuilles de Crataegus monogyna Jacq. et de Crataegus laevigata (Poiret) DC. En fonction de la période de végétation. Plantes Médicinales et Phytothérapie25(1):12-16.

Lee J, Finn CE, Wrolstad RE (2004). Comparison of anthocyanin pigment and other phenolic compounds of Vacinium membranaceum and Vaccinium ovatum native to the Pacific Northwest of North America. Journal of Agricultural and Food Chemistry. 52(23):7039-7044.

Marinova D, Ribarova F, Atanassova M (2005). Total phenolics and total flavonoids in Bulgarian fruits and vegetables. Journal of Chemical Technology and Metallurgy 40(3):255-260.

Nindo CI, Tang J, Powers JR, Singh P (2005). Viscosity of blueberry and raspberry juices for processing applications. Journal of Food Engineering 69:343-35.

Ochmian I, Kozos K, Chelpinski P, Szczepanek M (2015). Comparison of berry quality in highbush blueberry cultivars grown according to conventional and organic methods. Turkish Journal of Agriculture and Forestry39:174-181.

Okan OT, Varlibaş H, ÖzM, Deniz İ(2013). Antioxidant analysis methods and some non-wood forest plant products as sources of antioxidants in Eastern Black Sea region. Kastamonu University Journal of Forestry Faculty 13(1):48-59.

Peltola R (2013). Relevance of production area characternstics for NWFP demand and markets. In: Non-wood forest products, health and wellbeing. Publisher University of Helsinki Ruralia Institute: Espoo, Finland pp 35-36.

Pietta P, Gardana C, Pietta A (2003). Flavonoids in Herb. In: Evans CAR, Packer L (Eds). Flavonoids in Health and Disease. Marcel Dekker Inc, New Yorkpp 43-69.

Prior LR, Cao G, Martin A, Sofic E, Mcewen J, O’Brien C, Lischner N, Ehlenfeldt M, Kalt W, Krewer G, Mainland MC (1998). Antioxidant capacity as influenced by total phenolic and anthocyanin content, 
652

maturity and variety of Vaccinium species. Journal of Agricultural and Food Chemistry 46:2686-2693.

Raghvendra VS, Sharma V, Shakya A, Hedaytullah MD, Arya GS, Mishra A, Gupta AG, Pachpute AP, Patel D (2011). Chemical and potential aspects of anthocyanins-a water-soluble vacuolar flavonoid pigments: A review. International Journal of Pharmaceutical Sciences Review and Research 6(1):28-33.

Ribera AE, Reyes-Diaz M, Alberdi M, Zuniga GE, Mora M L (2010). Antioxidant compound in skin and pulp of fruit changed among genotypes and maturity stages in highbush blueberry (Vaccinium corymbosum $L$.) grown in southern Chile. Journal of Soil Science and PlantNutrition 10(4): 509-536.

Samad NB, Debnath T, Ye M, Hasna AM, Lim OB (2014). In vitro antioxidant and anti-inflammatory activities of Korean blueberry (Vaccinium corymbosum L.) extracts. Asian Pacific Journal of Tropical Biomedicine 4(10):807-815.

Sawa T, Nakao M, Akaike T, Ono K, Maeda H (1999). Alkylperoxyl radical-scavenging activity of various flavonoids and other phenolic compounds: Implications for the anti-tumor-promoter effect of vegetables. Journal of Agricultural and Food Chemistry 47:397-402.

Seeram NP, Adams LS, Zhang Y, Lee R, Sand D, Scheuller HS, Heber D (2006). Blackberry, black raspberry, blueberry, cranberry, red raspberry and strawberry extracts inhibit growth and stimulate apoptosis of human cancer cells in vitro. Journal of Agricultural and Food Chemistry 54(25):9329-9339.

Singleton VL, Orthofer R, Raventos RML (1999). Analysis of total phenols and other oxidation substrates and antioxidants by means of FolinCiocalteu reagent. In: Lester P (Ed). Methods in Enzymology. Academic Press 152-178.
Solovchenko A, Schmitz-Eiberger M (2003). Significance of skin flavonoids for UV-B-protection in apple fruits. Journal of Experimental Botany 54(389):1977-1984

StöhrH,Herrmann K(1975). The phenolics of fruits, VI. In: The phenolics of currants, gooseberries and blueberries. Changes in phenolic acids and catechins during development of black currants. Z Lebensm-Unters Forsch 159:31-37.

Taruscio TG, Barney DL, Exon J (2004). Content and profile of flavanoid and phenolic acid compounds in conjunction with the antioxidant capacity for a variety of northwest Vaccinium berries. Journal of Agricultural and Food Chemistry 52(10):3169-3176.

Uzelac VD, Savic Z, Brala A, Levaj B, Kavacevic DB, Bisko A (2010). Evaluation of phenolic content and antioxidant capacity of blueberry cultivars (Vaccinium corymbosum l.) grown in the Northwest Croatia. Food Technology and Biotechnology 48(2):214221.

Yang G, Yue J, GongX, Qian B, Wang H, Deng Y, Zhao Y (2014). Blueberry leaf extracts incorporated chitosan coatings for preserving postharvest quality of fresh blueberries. Postharvest Biology and Technology 92:46-53.

Zheng W, Wang SY (2003). Oxygen radical absorbing capacity of phenolics in blueberries, cranberries, chokeberries, and lingonberries. Journal of Agricultural and Food Chemistry 51:502-509.

Zheng Y, Wang YC, Wang SY, Zheng W (2003). Effect of high-oxygen atmospheres on blueberry phenolics, anthocyanins, and antioxidant capacity. Journal of Agricultural and Food Chemistry 51:7162-7169.

Zimmer KR, Blum-Silva CH, Souza ALK, Wulfsschuch M, Reginatto HF, Pereira CMP,Macedo AJ,Lencina LC (2014). The antibiofilm effect of blueberry fruit cultivars against Staphylococcus epidermidis and Pseudomonas aeruginosa.Journal of Medicinal Food 17(3):324331. 